\title{
Effects of exogenous application of five antioxidants on vigour, viability, oxidative metabolism and germination enzymes in aged cabbage and lettuce seeds
}

\author{
Ademola Emmanuel Adetunji ${ }^{\mathrm{a}, *}$, Sershen $^{\mathrm{b}, \mathrm{c}}$, Boby Varghese ${ }^{\mathrm{a}}$, Norman Pammenter ${ }^{\mathrm{a}}$ \\ ${ }^{a}$ School of Life Sciences, University of KwaZulu-Natal, Durban 4001, South Africa \\ ${ }^{\mathrm{b}}$ Department for Biodiversity and Conservation Biology, University of the Western Cape, Private Bag X17, Bellville 7535, South Africa \\ ${ }^{\mathrm{c}}$ Institute of Natural Resources, P.O. Box 100396, Scottsville 3209, South Africa
}

\section{A R T I C L E I N F O}

\section{Article History:}

Received 21 March 2020

Revised 28 August 2020

Accepted 5 October 2020

Available online 22 October 2020

Edited by PN Hills

\section{Keywords:}

Controlled deterioration

Electrolyte leakage

Germination

Invigoration

Stress

\begin{abstract}
A B S T R A C T
Ageing induces modifications capable of compromising seed vigour and viability. This study investigated the effects of exogenous application of five antioxidants: ascorbic acid (AA), gallic acid (GA), reduced glutathione (GSH), trolox and glycerol, on physical and biochemical lesions induced by controlled deterioration (CD) in Brassica oleracea (cabbage) and Lactuca sativa (lettuce) seeds. The antioxidants were applied at 0.2, 0.4 and $0.6 \mathrm{mM}$ to fresh seeds and seeds subjected to CD: $75 \%$ viability (P75), 50\% viability (P50) and $25 \%$ viability (P25); deionised water (DW) served as control. Controlled deterioration resulted in more abnormal seedlings production in cabbage than in lettuce seeds. Additionally, CD increased electrical conductivity (EC) and protein carbonylation (PC), lowered antioxidant and germination enzymes activities in both species but increased lipid peroxidation in lettuce seeds only. Exogenous application of antioxidants enhanced seed viability of cabbage at P25 and lettuce at P50 and P25; seedling vigour of fresh, P75 and P25 cabbage; P50 and P25 lettuce seeds. Electrolyte conductivity and lipid peroxidation were reduced by AA, GA, glycerol, GSH and trolox in lettuce seeds, while PC was reduced by GA, glycerol and GSH in both species. Antioxidant and germination enzymes activities were heightened by GA, glycerol, GSH, and trolox in cabbage seeds; AA, GA, glycerol, GSH and trolox in lettuce seeds. While DW reduced PC in cabbage seeds, it reduced lipid peroxidation and heightened antioxidant and germination enzymes activities in lettuce seeds. The study resolved that CDinduced lesions differ in both species, and the exogenously applied antioxidants are beneficial in quelling injurious spin-offs of oxidative reactions.
\end{abstract}

(C) 2020 SAAB. Published by Elsevier B.V. All rights reserved.

\section{Introduction}

Seeds gradually and continuously suffer post-harvest deterioration leading to quality loss during prolonged storage (Sahu et al., 2017). This process of ageing causes delayed germination, reduced vigour and eventual total viability loss (Boniecka et al., 2019). The higher the seed moisture level and temperature at which seeds are stored, the faster they lose viability (Simon, 1974). Significant physiological and biochemical symptoms of ageing reported in various species include increased susceptibility to disease, reduced respiration (Ferguson et al., 1990), enzyme degradation and inactivation (Dell'aquila, 1994), genetic degradation (Sen and Osborne, 1977; Basra et al., 2003), loss of membrane integrity (Mira et al., 2011) and increased incidence of morphologically abnormal seedlings (Simon, 1974).

\footnotetext{
* Corresponding author.

E-mail address: adetunjiademola@hotmail.com (A.E. Adetunji).
}

The decline in seed quality during storage in most species investigated to date has been attributed to the generation of reactive oxygen species (ROS) (Groot et al., 2015; Chandra et al., 2019). An imbalance between the generation of ROS and antioxidant protection against them induces oxidative stress (Berjak and Pammenter, 2013; Choudhury et al., 2017; Chandra et al., 2019) which brings about tissue damage by releasing prooxidants capable of driving the Fenton reaction and lipid peroxidation, and by degrading defensive antioxidants (Gutteridge, 1995). Reactive oxygen species have also been implicated in protein oxidation, and damage of DNA, RNA and carbohydrates in a wide range of plant tissues (Hawkins et al., 2009; Mittler, 2017), including those within seeds (Ferguson et al., 1990; Bailly et al., 2008).

However, studies on ageing in orthodox seeds have also indicated that the mechanism(s) of seed deterioration may differ across species. For instance, while seed viability loss has been associated with lipid peroxidation in numerous species (Al-maskri et al., 2002 on Cucumis sativus; Sahu et al., 2017 on Pongamia pinnata), van Staden 
et al. (1976) showed that this was unlikely the case in stored Protea compacta seeds; Priestley and Leopold (1979) suggested that lipid peroxidation might be unconnected with ageing in Glycine max seeds; and deterioration was accompanied by lipid peroxidation in lettuce (Smith, 1986; Mira et al., 2010; Xue et al., 2001) but not cabbage seeds (Mira et al., 2011). A study on Arachis hypogea seeds (Pearce and Samad, 1980) may offer some explanation for these inconsistencies in terms of the involvement of lipid peroxidation in ageing. The authors attributed ageing in A. hypogea seeds to the inability to regulate intracellular concentrations or subcellular segmentation of metabolites due to loss of membrane lipids and not peroxidation.

Given the above, the identification of biochemical markers of oxidative stress has become a popular area of investigation in terms of seed deterioration (Murthy et al., 2003; Kim et al., 2010; Boniecka et al., 2019). These markers range from ROS and antioxidants (enzymic and nonenzymic) to products of oxidative processes (e.g. lipid peroxides [Parkhey et al., 2012]) and products of proteins oxidation or carbonyls [Job et al., 2005]). Assessing levels of antioxidant protection are just as important as measuring oxidative injury when investigating oxidative stress in biological systems (Moran et al., 1994). In this regard, antioxidants including detoxifying enzymes such as superoxide dismutase (SOD), peroxidase (POD), glutathione reductase (GR), catalase (CAT) and ascorbate peroxidase (APX) are often used as indicators of seed deterioration (Kim et al., 2010; Yan et al., 2016; Boniecka et al., 2019) given their role in defending plant tissues against oxidative stress (Sahu et al., 2017; Wang et al., 2018). Seed ageing has also been shown to be accompanied by a decline in the activity of germination enzymes like $\alpha$-amylase (Livesley and Bray, 1991; Ganguli and Sen-Mandi, 1993) and several studies have shown the involvement of $\beta$-1,3-glucanase in seed germination by promoting radicle protrusion (Leubnermetzger and Meins, 1999; Koornneef et al., 2002; LeubnerMetzger, 2003).

There are reports that some of the effects of seed deterioration (induced by ageing) may be reversed to an extent by soaking treatments which can restore vigour (Bedi et al., 2006; Kibinza et al., 2011). Seeds treatments involving soaking in aqueous antioxidant solutions such as ascorbic acid (Burguieres et al., 2007), glutathione (Draganić and Lekić, 2012) and tocopherol (Afzal et al., 2006) have been reported to enhance seed germination, vigour and subsequent seedling growth in several species. Likewise, glycerol, a known radioprotectant (Ab Hamid et al., 2014; Yatim et al., 2016), has been shown to reduce ROS production in stress exposed seed embryonic axes (Sershen et al., 2012) and increase cellular viscosity in dehydrating seed tissues (Morris et al., 2006) and enhance growth in several species (Tisserat and Stuff, 2011). Many enzymic (ascorbate peroxidase, catalase, glutathione reductase and superoxide dismutase) and nonenzymic (ascorbic acid, gallic acid, reduced glutathione and $\alpha$-tocopherol) antioxidants (Bailly, 2004; Job et al., 2005), have been reported to alleviate oxidative stress in seeds and seed-derived explants (Qiusheng et al., 2005; North et al., 2012). Antioxidants have also been used as soaking treatment solutions for seeds of species such as Ablemoschus esculentus (Raza et al., 2013), Pisum sativum (Benamar et al., 2003), resulting in an improvement in their endogenous antioxidant enzymes activities, pigments, seed vigour, growth and yield and mitochondria performance. Since differences in seed vigour are mainly accredited to ageing (Powell and Matthews, 2005), an improvement in the germination of deteriorated seeds after application of soaking treatments involving antioxidants can be indicative of the amelioration of oxidative stress.

The present study investigated the effects of exogenous application of a range of antioxidants (ascorbic acid, gallic acid, glycerol, reduced glutathione, trolox) on germination and seedling vigour in controlled deteriorated cabbage and lettuce seeds. Where these treatments alleviated the effects of ageing on vigour and viability, established physical and biochemical markers of oxidative stress and germinability were assayed to identify the mechanism of action of these antioxidants. These physical and biochemical markers were also measured in fresh and aged but unsoaked seeds to compare the mechanism(s) of ageing in these species.

\section{Materials and methods}

\subsection{Seed material}

Commercial seeds of Brassica oleracea L. (cabbage, 'Glory of Enkhuizen') and Lactuca sativa L. (lettuce, 'Great Lakes'), supplied in hermetically sealed bags, were obtained from McDonalds Seeds (Pietermaritzburg, South Africa) and stored at $4{ }^{\circ} \mathrm{C}$ before being directed towards the experiments described below. Once the bags were opened, seeds were transferred into air-tight metal cans and stored at $4{ }^{\circ} \mathrm{C}$. All seeds were used within three months of being stored.

\subsection{Seed vigour assessment}

Seeds were removed from storage at $4{ }^{\circ} \mathrm{C}$ and maintained at room temperature overnight before use. Each seed lot was subjected to an initial germination and vigour test (three replicates of 25 seeds) before being subjected to the $\mathrm{CD}$ and application of antioxidants as described below. Only seed lots that showed germination $>85 \%$ (in cabbage) and $>95 \%$ (in lettuce) within $48 \mathrm{~h}$ of sowing were used in subsequent experiments.

\subsection{Controlled deterioration}

Seed moisture content (MC,\%) was determined on fresh mass basis using the adjusted low constant temperature oven method recommended by International Seed Testing Association (ISTA) for crop seeds (Komba et al., 2006). Controlled deterioration, a vigour declining approach that indicates storage longevity of seeds (Powell and Matthews, 2005; Mavi and Demir, 2007; Demir and Mavi, 2008) was used to simulate seed ageing following the methods described by Tekrony (2005) with slight modifications. The detailed methods are described in Adetunji et al., 2020) but very briefly, seed MC (\%) was raised to $11 \%$ in an air-tight plastic vessel $(134 \times 102 \times 70 \mathrm{~mm})$ containing saturated potassium chloride $(\mathrm{KCl})$ salt solution and maintained at $25{ }^{\circ} \mathrm{C}$ for $24 \mathrm{~h}$ to reach the target MC: MC was raised from $5.5 \%$ to $11 \%$ in cabbage and $5.7 \%$ to $11 \%$ in lettuce. Thereafter, the vessels were placed in an incubator (Heraeus FB 420, Hanau, Germany) set at $35^{\circ} \mathrm{C}$.

Every $24 \mathrm{~h}$, four replicates of 25 seeds were removed from the vessels and sown between two layers of germination paper (Anchor Paper Co., Saint Paul, USA) moistened with $3 \mathrm{ml}$ deionised water (DW), within Petri dishes and incubated at $20 \pm 2{ }^{\circ} \mathrm{C}$ and a $16: 8 \mathrm{~h}$ photoperiod. Seedling production (\%), discriminating between normal (including seedlings that were considered abnormal on germination but later became normal) and abnormal (with shoot growth but root length $<2 \mathrm{~mm}$ ) growth (Fig. S1), was assessed 14 days after sowing (DAS). Seeds that developed chlorophyllous cotyledons but failed to germinate and seedlings that died within 14 DAS were scored as dead. The experiment was repeated twice for cabbage and three times for lettuce (as the data were more variable for the latter). The normal seedling (\%) data were used to construct a CD curve for each species (Fig. S2 A and B) which was used to identify the time (days) to $75 \%$ viability (P75), 50\% viability (P50) and 25\% viability (P25), hereafter referred to as P75, P50 and P25 seeds, respectively. Fresh seeds (viability: cabbage, $>85 \%$; lettuce, $>95 \%$ ) served as the control. 


\subsection{Application of exogenous antioxidant solutions}

When seeds are treated with exogenous solutions by soaking for invigoration, it is important to first determine the treatment duration as seeds should not germinate in the treatment solutions. This is because ROS is also involved in germination (Job et al., 2005; Verma et al., 2015) and exposure to antioxidants during germination can compromise radicle emergence. In the present study, seeds of both species were imbibed in DW for various time periods to generate an imbibition curve (Fig. S3) which was used to identify an imbibition time associated with phase 2 of germination (period of early germination processes before radicle protrusion; Varier et al., 2010). Based on these data, an imbibition time of $8 \mathrm{~h}$ for cabbage and $6 \mathrm{~h}$ for lettuce, was used for all subsequent antioxidant treatments.

Fresh, P75, P50 and P25 seeds of both species were soaked in aqueous solutions of ascorbic acid (AA), gallic acid (GA), reduced glutathione (GSH), trolox (an analogue of $\alpha$-tocopherol) and glycerol. The exogenous antioxidants were applied at three concentrations, $0.2 \mathrm{mM}, 0.4 \mathrm{mM}$ and $0.6 \mathrm{mM}$, and deionised water (DW) served as control. This is based on the fact that a wide range of antioxidants applied exogenously at concentrations in this range has been shown to be beneficial in alleviating oxidative stress-induced lesions, enhancing germination, vigour and seed storability of several plant species (Amjad et al., 2007; Ozfidan-Konakci et al., 2015; Kuchlan et al., 2017). Applying the different antioxidants at three similar concentrations allowed for the comparison of effects within and across antioxidants. For each treatment combination (CD level $\times$ antioxidant $\times$ concentration), four replicates of 25 seeds were soaked in $3 \mathrm{ml}$ of antioxidant solution/DW for $8 \mathrm{~h}$ in cabbage and $6 \mathrm{~h}$ in lettuce. Seeds were removed from soaking, blotted dry with paper towel and assessed for germination as described for the CD experiments. Percentage seedling production (normal and abnormal) was assessed 14 DAS. Root and shoot length measurements were also taken 14 DAS and used to calculate seedling vigour index (AbdulBaki and Anderson, 1973).

\subsection{Evaluation of biochemical markers of oxidative stress and germinability}

Where specific CD level $\times$ antioxidant $\times$ antioxidant concentration combinations resulted in enhanced production of normal seedlings relative to seeds soaked in DW, seeds were exposed to these selected treatment combinations and assessed immediately after soaking for electrolyte leakage and a range of biochemical markers of oxidative stress and germinability. The detailed assay methods are described in Adetunji et al. (2020). For comparative purposes, two controls were used for the electrolyte leakage and biochemical marker assays: seeds aged to the appropriate CD level and (1) soaked in DW and (2) unsoaked. Seeds were blotted dry before processing them for all assays.

\subsubsection{Electrolyte conductivity}

Electrolyte leakage was measured in seeds using a CM100-2 multi-cell conductivity metre (Reid \& Associates, Durban, South Africa) following Sershen et al. (2016) with slight modifications. Individual seeds $(n=5)$ were soaked in $2 \mathrm{ml}$ of antioxidant solution/ DW for $8 \mathrm{~h}$. The conductivity of the soaking treatment $(1.5 \mathrm{ml})$ was measured. Seeds were dried in an oven (Gallenkamp IH-150, London, England) at $80{ }^{\circ} \mathrm{C}$ for $48 \mathrm{~h}$ and weighed to determine the dry mass (DM). Deionised water and the respective antioxidant solutions (incubated without seeds for $8 \mathrm{~h}$ ) were used as blanks. Leakage was expressed as $\mathrm{mS} / \mathrm{cm} / \mathrm{g}$ DM.

\subsubsection{Conjugated dienes}

Conjugated dienes were estimated as described by Parkhey et al. (2012) using three replicates of $0.25 \mathrm{~g}$ of seed.
Conjugated dienes levels were calculated using an extinction coefficient of $25 \mathrm{mM}^{-1} \mathrm{~cm}^{-1}$ and expressed as $\mu \mathrm{mol} / \mathrm{g}$ FM.

\subsubsection{4-Hydroxy-2-nonenal (4-HNE)}

The estimation of 4-HNE followed the processes described by Parkhey et al. (2012) using three replicates of $0.25 \mathrm{~g}$ of seed. The 4HNE content was calculated using an extinction coefficient of 13,750 $M^{-1} \mathrm{~cm}^{-1}$ and expressed as $\mu \mathrm{mol} / \mathrm{g}$ FM.

\subsubsection{Protein carbonylation}

Protein (three replicates of $2 \mathrm{~g}$ of seed each) was extracted in sodium phosphate buffer ( $\mathrm{pH} 7.4$ ) according to Juszczuk et al. (2008). Total protein content was first determined according to (Bradford, 1976) and the extracts were diluted with DW to a protein concentration of $10 \mathrm{mg} / \mathrm{ml}$. Protein carbonyl content was estimated following the spectrophotometric method described by Augustyniak et al. (2015). Carbonyl content was calculated using a molar absorption coefficient of 22,000 $\mathrm{M}^{-1} \mathrm{~cm}^{-1}$ and expressed as $\mathrm{nM}$ carbonyl/mg protein.

\subsection{Enzymic antioxidant activity}

The enzyme extraction procedure followed Farrant et al. (2004). Seeds (three replicates of $0.25 \mathrm{~g}$ of seed each) were homogenized using liquid nitrogen in $4 \mathrm{ml}$ of extraction buffer ( $0.1 \mathrm{M}$ sodium phosphate buffer [pH7.8], $0.1 \mathrm{mM}$ ethylenediaminetetraacetic acid, $2 \mathrm{mM}$ dithiothreitol, $1.25 \mathrm{mM}$ polyethylene glycol 4000 and $0.1 \mathrm{~g}$ polyvinylpyrrolidone). The extract was centrifuged (Model J-E, Beckman Coulter Avanti ${ }^{\circledR}$, La Brea, CA, USA) at $16,000 \times \mathrm{g}$ for $30 \mathrm{~min}$ at $4{ }^{\circ} \mathrm{C}$. The supernatant was collected and used for catalase, glutathione reductase and superoxide dismutase estimations as described below.

\subsubsection{Catalase activity}

Catalase was assayed according to Claiborne (1985). The decomposition of $\mathrm{H}_{2} \mathrm{O}_{2}$ was measured as a decline in absorbence at $240 \mathrm{~nm}$. Catalase activity was calculated using an extinction coefficient of $0.0436 \mathrm{mM}^{-1} \mathrm{~cm}^{-1}$ and expressed as $\mu \mathrm{mol} \mathrm{H}_{2} \mathrm{O}_{2}$ decomposed $/ \mathrm{min} /$ $\mathrm{g} /$ fresh mass (FM).

\subsubsection{Glutathione reductase}

The method described by Esterbauer and Grill (1978) and modified by Farrant et al. (2004) was used to estimate the activity of glutathione reductase (GR). GR activity was based on the rate of NADPH oxidation in $5 \mathrm{~min}$ at $25^{\circ} \mathrm{C}$. The decline in absorbence was read at $340 \mathrm{~nm}$ using $50 \mathrm{mM}$ potassium phosphate buffer ( $\mathrm{pH} 7.8$ ) as a blank. GR activity was calculated using the extinction coefficient $6.22 \mathrm{mM}^{-1}$ $\mathrm{cm}^{-1}$ and expressed as $\mu$ mol NADPH oxidised/min/g FM.

\subsubsection{Superoxide dismutase}

Superoxide dismutase (SOD) was estimated following the method of Beauchamp and Fridovich (1971) as modified by Varghese et al., 2011. The enzyme activity was calculated using the enzymic inhibition of the photoreduction of NBT. A unit of SOD corresponded to 50\% inhibition of photoreduction of nitro blue tetrazolium to blue formazan by the enzyme. SOD activity was expressed as units of SOD/g FM.

\subsection{Germination enzymes activities}

Seeds (three replicates of $0.25 \mathrm{~g}$ each) were used for the following assays.

\subsection{1. $\alpha$-amylase}

The enzyme was extracted following the method of Biswas et al. (1978) with slight modifications by Farashah et al. (2011). $\alpha$-amylase was measured following the methods of Bernfeld (1955) and Baker (1991). The reducing sugar (maltose) liberated was estimated using a 
maltose standard curve, and $\alpha$-amylase activity was expressed in $\mu \mathrm{mol} / \mathrm{min} / \mathrm{ml} / \mathrm{g}$ FM.

\subsection{2. $\beta$-1,3-glucanase activity}

The enzyme extraction method followed Farashah et al. (2011). Total $\beta$-1,3-glucanase activity was assayed following the description of Celestino et al. (2006). The reducing sugar liberated was estimated using a glucose standard curve, and $\beta$-1,3-glucanase activity was expressed in $\mu \mathrm{mol} / \mathrm{min} / \mathrm{ml} / \mathrm{g}$ FM.

\subsection{Statistical analysis}

All data analyses were performed using IBM SPSS Statistics (Ver. 26.0. Armonk, NY, USA). All data were tested for normality using a Shapiro-Wilk test. All percentage data were arcsine transformed before analysis. To test for significant differences across treatments and controls, data for normal seedling (\%), vigour index and all biochemical parameters were subjected to analysis of variance (ANOVA) where data were parametric. A Tukey post-hoc test was used for separation of means. Where data did not satisfy ANOVA assumptions, even after transformation, a Kruskal-Wallis test was used. All differences were considered significant at 0.05 probability level.

\section{Results}

\subsection{Effect of controlled deterioration (CD) and the exogenous application of antioxidants on seedling growth and vigour of cabbage and lettuce seeds}

Seeds subjected to CD produced normal and abnormal seedlings in both species (Fig. S1). The occurrence of abnormal seedlings was limited $(0.5-1.5 \%)$ in fresh cabbage seeds and observed in only three soaking treatments but increased substantially in controlled deteriorated $(\mathrm{CDd})$ seeds across all soaking treatments (Table S1). Similarly, in lettuce the occurrence of abnormal seedlings was minimal $(0.5-1.0 \%)$ in fresh seeds and limited to four soaking treatments (Table S1). With $\mathrm{CD}$, the abnormal seedlings were observed across relatively more soaking treatments, but the percentage occurrence was only slightly higher $(0.5-4 \%)$ than those observed in fresh seeds. In L50 lettuce seeds, $0.6 \mathrm{mM} \mathrm{GA}, 0.2 \mathrm{mM}$ glycerol and $0.2 \mathrm{mM} \mathrm{GSH}$ significantly increased abnormal seedlings produced relative to DW.

Percentage normal seedling production in fresh, P75 and P50 cabbage seeds was not influenced significantly by the application of exogenous antioxidants, when compared with seeds soaked in deionised water (DW) (Table S2). At P25, however, normal seedling production was increased significantly relative to P25-DW-treated seeds in the following soaking treatments: $0.2 \mathrm{mM} \mathrm{GA}, 0.2$ and $0.4 \mathrm{mM}$ glycerol, $0.6 \mathrm{mM} \mathrm{GSH}$ and $0.2 \mathrm{mM}$ trolox (Table 1).

In lettuce, normal seedling production in fresh and P75 seeds was not influenced significantly by the application of exogenous antioxidants when compared with seeds soaked in DW (Table S3). At P50, however, normal seedling production was significantly increased relative to P50-DW-treated seeds in the following soaking treatments: $0.6 \mathrm{mM}$ of AA, GA, glycerol; $0.4 \mathrm{mM}$ and $0.6 \mathrm{mM}$ GSH (Table 2). Additionally, at P25, normal seedling production was significantly increased relative to P25-DW-treated seeds in the following soaking treatments: $0.2,0.4$ and $0.6 \mathrm{mM}$ of $\mathrm{AA}, \mathrm{GSH} ; 0.6 \mathrm{mM}$ glycerol; 0.2, 0.4 and $0.6 \mathrm{mM}$ of trolox.

Seedling vigour index (SVI) in fresh cabbage seeds was significantly increased when treated with $0.2,0.4$ and $0.6 \mathrm{mM} \mathrm{GA}$ and glycerol, and $0.2 \mathrm{mM}$ trolox when compared with fresh seeds soaked in DW (Table 3). However, SVI was only significantly increased in P75 cabbage seeds when they were treated with $0.4 \mathrm{mM}$ trolox when compared with P75 seeds soaked in DW. Seedling vigour index in P50 cabbage seeds was not influenced significantly by antioxidant application compared with P50-DW-treated seeds (Table S4), while
Table 1

Effect of exogenous application of antioxidants on normal seedling production (\%) in fresh and controlled deteriorated (P25) cabbage seeds.

\begin{tabular}{lll}
\hline Soaking treatments & $\begin{array}{l}\text { \% Normal seedlings for } \\
\text { fresh seeds }\end{array}$ & $\begin{array}{l}\text { \% Normal seedlings for } \\
\text { P25 seeds }\end{array}$ \\
\hline DW & $90.50 \pm 5.21^{\mathrm{NS}}$ & $23.50 \pm 8.40^{\mathrm{b}}$ \\
$\mathrm{AA}(0.2 \mathrm{mM})$ & $85.50 \pm 7.39^{\mathrm{NS}}$ & $34.50 \pm 5.21^{\mathrm{NS}}$ \\
$\mathrm{AA}(0.4 \mathrm{mM})$ & $94.00 \pm 2.14^{\mathrm{NS}}$ & $34.50 \pm 2.98^{\mathrm{NS}}$ \\
$\mathrm{AA}(0.6 \mathrm{mM})$ & $87.50 \pm 5.13^{\mathrm{NS}}$ & $31.00 \pm 6.32^{\mathrm{NS}}$ \\
$\mathrm{GA}(0.2 \mathrm{mM})$ & $85.00 \pm 7.41^{\mathrm{NS}}$ & $39.00 \pm 9.01^{\mathrm{a}}$ \\
GA $(0.4 \mathrm{mM})$ & $91.50 \pm 7.23^{\mathrm{NS}}$ & $28.50 \pm 4.50^{\mathrm{NS}}$ \\
GA $(0.6 \mathrm{mM})$ & $88.50 \pm 6.91^{\mathrm{NS}}$ & $27.00 \pm 9.26^{\mathrm{NS}}$ \\
Glycerol $(0.2 \mathrm{mM})$ & $90.50 \pm 7.07^{\mathrm{NS}}$ & $42.00 \pm 8.28^{\mathrm{a}}$ \\
Glycerol $(0.4 \mathrm{mM})$ & $90.50 \pm 3.66^{\mathrm{NS}}$ & $43.50 \pm 8.40^{\mathrm{a}}$ \\
Glycerol $(0.6 \mathrm{mM})$ & $89.00 \pm 4.66^{\mathrm{NS}}$ & $22.00 \pm 3.02^{\mathrm{NS}}$ \\
GSH $(0.2 \mathrm{mM})$ & $81.00 \pm 13.65^{\mathrm{NS}}$ & $32.50 \pm 9.18^{\mathrm{NS}}$ \\
GSH $(0.4 \mathrm{mM})$ & $87.50 \pm 7.54^{\mathrm{NS}}$ & $34.50 \pm 6.74^{\mathrm{NS}}$ \\
GSH $(0.6 \mathrm{mM})$ & $87.50 \pm 4.99^{\mathrm{NS}}$ & $38.00 \pm 7.71^{\mathrm{a}}$ \\
Trolox $(0.2 \mathrm{mM})$ & $85.50 \pm 7.39^{\mathrm{NS}}$ & $36.00 \pm 8.00^{\mathrm{a}}$ \\
Trolox $(0.4 \mathrm{mM})$ & $90.50 \pm 4.24^{\mathrm{NS}}$ & $30.00 \pm 5.24^{\mathrm{NS}}$ \\
Trolox $(0.6 \mathrm{mM})$ & $87.50 \pm 7.54^{\mathrm{NS}}$ & $32.50 \pm 4.50^{\mathrm{NS}}$ \\
\hline
\end{tabular}

Values represent mean $\pm \mathrm{SD}(4 \times n=25)$ of control (fresh cabbage seeds soaked in deionised water [DW] and all the exogenously applied antioxidants) and cabbage seeds at CD level (P25) where the exogenously applied antioxidants changed normal seedling production (\%) significantly relative to DW. Values labelled with different letters are significantly different $(P<0.05$, ANOVA $)$ when compared across soaking treatments within each CD level. NS: not significantly different from value obtained with DW and therefore not considered in statistical comparisons.

SVI in P25 seeds was significantly increased relative to P25-DWtreated seeds when treated with 0.2 and $0.4 \mathrm{mM}$ glycerol (Table 3).

In fresh and P75 lettuce seeds, SVI was not influenced significantly by antioxidant application compared with their DW-treated seeds (Table S5). However, SVI in P50 lettuce seeds was significantly increased relative to P50-DW-treated seeds when treated with GA $(0.6 \mathrm{mM})$ and trolox $(0.2,0.4$ and $0.6 \mathrm{mM})$, while SVI in P25 seeds was significantly increased when treated with $0.2 \mathrm{mM} \mathrm{AA}, 0.6 \mathrm{mM}$ GSH and trolox (0.2, 0.4 and $0.6 \mathrm{mM})$ compared with P25-DWtreated seeds (Table 4).

\subsection{Effects of $C D$ and the exogenous application of antioxidants on biomarkers of oxidative stress in cabbage and lettuce seeds}

The oxidative stress biomarkers were measured in fresh and CDd seeds without soaking (unsoaked), and after soaking in DW, and all $\mathrm{CD} \times$ antioxidant $\times$ concentration treatment combinations (termed 'beneficial soaking treatments' henceforth) that changed normal seedling production (\%) significantly relative to DW-treated seeds at a specific level of $C D$.

Controlled deterioration led to heightened solute leakage, measured as electrolyte conductivity (EC), in unsoaked cabbage and lettuce seeds relative to their unsoaked fresh seeds but these differences were only significant at P50 and P25 (Table 5). The beneficial soaking treatments did not extenuate leakage in P25 cabbage seeds relative to unsoaked P25 seeds; rather, DW, GA $(0.2 \mathrm{mM})$ and trolox $(0.2 \mathrm{mM})$ caused a further increase in EC levels in P25 cabbage seeds (Fig. 1A). However, in P50 lettuce seeds, soaking in $0.6 \mathrm{mM}$ of AA, GA, glycerol and GSH significantly decreased EC levels relative to unsoaked and DW-treated P50 seeds; glycerol $(0.6 \mathrm{mM})$ resulted in a particularly low EC level relative to the other beneficial soaking treatments (Fig. 1B). Similarly, EC levels in P25 lettuce seeds soaked in 0.6 $\mathrm{mM}$ of $\mathrm{AA}$, glycerol, GSH and trolox were significantly reduced relative to unsoaked and DW-treated P25 seeds (Fig. 1C). Glycerol (0.6 $\mathrm{mM})$ and $\mathrm{GSH}(0.6 \mathrm{mM})$ led to particularly low EC levels relative to the other beneficial soaking treatments.

Controlled deterioration of cabbage seeds did not lead to a significant change in conjugated diene (CJD) levels relative to fresh cabbage seeds, but significantly increased CJD levels in P75, P50 and P25 
Table 2

Effect of exogenous application of antioxidants on normal seedling production (\%) in fresh and controlled deteriorated (P50 and P25) lettuce seeds.

\begin{tabular}{llll}
\hline Soaking treatments & \% Normal seedlings for fresh seeds & \% Normal seedlings for P50 seeds & \% Normal seedlings for P25 seeds \\
\hline DW & $98.00 \pm 3.02^{\mathrm{NS}}$ & $62.00 \pm 10.03^{\mathrm{b}}$ & $20.50 \pm 5.42^{\mathrm{c}}$ \\
$\mathrm{AA}(0.2 \mathrm{mM})$ & $93.00 \pm 4.14^{\mathrm{NS}}$ & $69.00 \pm 4.14^{\mathrm{NS}}$ & $45.00 \pm 8.21^{\mathrm{a}}$ \\
$\mathrm{AA}(0.4 \mathrm{mM})$ & $95.00 \pm 6.32^{\mathrm{NS}}$ & $70.50 \pm 10.89^{\mathrm{NS}}$ & $30.50 \pm 4.24^{\mathrm{b}}$ \\
$\mathrm{AA}(0.6 \mathrm{mM})$ & $95.50 \pm 4.78^{\mathrm{NS}}$ & $76.00 \pm 7.41^{\mathrm{a}}$ & $30.50 \pm 4.28^{\mathrm{b}}$ \\
GA $(0.2 \mathrm{mM})$ & $94.00 \pm 4.50^{\mathrm{NS}}$ & $72.00 \pm 2.83^{\mathrm{NS}}$ & $20.00 \pm 4.28^{\mathrm{NS}}$ \\
GA $(0.4 \mathrm{mM})$ & $96.00 \pm 5.24^{\mathrm{NS}}$ & $71.00 \pm 6.68^{\mathrm{NS}}$ & $20.00 \pm 6.76^{\mathrm{NS}}$ \\
GA $(0.6 \mathrm{mM})$ & $95.50 \pm 5.83^{\mathrm{NS}}$ & $76.00 \pm 3.70^{\mathrm{a}}$ & $24.50 \pm 4.99^{\mathrm{NS}}$ \\
Glycerol $(0.2 \mathrm{mM})$ & $95.00 \pm 7.33^{\mathrm{NS}}$ & $63.00 \pm 6.68^{\mathrm{NS}}$ & $23.00 \pm 5.13^{\mathrm{NS}}$ \\
Glycerol $(0.4 \mathrm{mM})$ & $97.00 \pm 4.66^{\mathrm{NS}}$ & $74.50 \pm 4.24^{\mathrm{NS}}$ & $28.00 \pm 9.56^{\mathrm{NS}}$ \\
Glycerol $(0.6 \mathrm{mM})$ & $98.50 \pm 2.98^{\mathrm{NS}}$ & $75.00 \pm 5.95^{\mathrm{a}}$ & $30.50 \pm 7.98^{\mathrm{b}}$ \\
GSH $(0.2 \mathrm{mM})$ & $97.50 \pm 5.63^{\mathrm{NS}}$ & $60.50 \pm 7.23^{\mathrm{NS}}$ & $35.00 \pm 6.68^{\mathrm{ab}}$ \\
GSH $(0.4 \mathrm{mM})$ & $94.00 \pm 4.78^{\mathrm{NS}}$ & $76.00 \pm 8.82^{\mathrm{a}}$ & $30.00 \pm 3.02^{\mathrm{b}}$ \\
GSH $(0.6 \mathrm{mM})$ & $97.50 \pm 2.98^{\mathrm{NS}}$ & $76.00 \pm 2.14^{\mathrm{a}}$ & $39.50 \pm 13.26^{\mathrm{ab}}$ \\
Trolox $(0.2 \mathrm{mM})$ & $98.00 \pm 2.14^{\mathrm{NS}}$ & $71.50 \pm 7.23^{\mathrm{NS}}$ & $33.00 \pm 5.95^{\mathrm{b}}$ \\
Trolox $(0.4 \mathrm{mM})$ & $97.50 \pm 3.66^{\mathrm{NS}}$ & $68.00 \pm 12.83^{\mathrm{NS}}$ & $44.00 \pm 10.47^{\mathrm{ab}}$ \\
Trolox $(0.6 \mathrm{mM})$ & $95.00 \pm 4.14^{\mathrm{NS}}$ & $69.00 \pm 13.14^{\mathrm{NS}}$ & $44.50 \pm 7.84^{\mathrm{a}}$ \\
\hline
\end{tabular}

Values represent mean \pm SD ( 4 x $n=25)$ of control (fresh lettuce seeds soaked in deionised water [DW] and all the exogenously applied antioxidants) and lettuce seeds at CD levels (P50, P25) where the exogenously applied antioxidants changed normal seedling production significantly relative to DW. Values labelled with different letters are significantly different $(P<0.05$, ANOVA) when compared across soaking treatments within each CD level. NS: not significantly different from value obtained with DW and therefore not considered in statistical comparisons.

lettuce seeds relative to fresh lettuce seeds (Table 5). Beneficial soaking treatments did not change CJD levels in P25 cabbage seeds relative to unsoaked P25 seeds (Fig. 1D). However, in P50 lettuce seeds, all beneficial soaking treatments significantly decreased CJD levels relative to unsoaked P50 seeds; and $0.6 \mathrm{mM}$ of GA, glycerol and GSH resulted in a greater reduction in CJD levels than DW (Fig. 1E). Similarly, all beneficial soaking treatments significantly reduced CJD levels in P25 lettuce seeds relative to unsoaked P25 seeds; the exogenous antioxidants resulted in a greater reduction in CJD levels than DW (Fig. 1F).

In cabbage seeds, $C D$ did not result in a significant change in 4HNE levels relative to fresh seeds, but in lettuce, CD significantly increased 4-HNE levels in P50 and P25 seeds relative to fresh seeds (Table 5). The levels of 4-HNE were significantly increased in P25 cabbage seeds soaked in $0.4 \mathrm{mM}$ glycerol (Fig. 1G) and P50 lettuce seeds soaked in $0.6 \mathrm{mM}$ glycerol (Fig. $1 \mathrm{H}$ ), while the other beneficial soaking treatments had no significant effect relative to unsoaked seeds;
$0.6 \mathrm{mM}$ of AA and GSH resulted in a greater reduction in 4-HNE levels of P50 lettuce seeds than DW. However, in P25 lettuce seeds, all exogenous antioxidants reduced 4-HNE levels significantly relative to unsoaked and DW-treated P25 seeds (Fig. 1I).

Controlled deterioration led to a significant rise in protein carbonylation (PC) levels in cabbage and lettuce seeds but these differences were only significant at P50 and P25 in cabbage, and P25 in lettuce seeds (Table 5). The PC levels were reduced significantly in P25 cabbage seeds soaked in all beneficial soaking treatments relative to unsoaked seeds; and $0.2 \mathrm{mM} \mathrm{GA}, 0.4 \mathrm{mM}$ glycerol and $0.6 \mathrm{mM}$ GSH resulted in a greater reduction in PC levels than DW (Fig. 1J). In P50 lettuce seeds, soaking in GA $(0.6 \mathrm{mM})$ and GSH $(0.6 \mathrm{mM})$ significantly reduced PC levels while the remaining exogenous antioxidants had no significant effect relative to unsoaked and DW-treated seeds (Fig. 1K). The PC levels were reduced significantly in P25 lettuce seeds soaked in AA (0.2 $\mathrm{mM})$, glycerol $(0.6 \mathrm{mM})$ and $\mathrm{GSH}(0.6 \mathrm{mM})$ while trolox $(0.6 \mathrm{mM})$ and DW had no significant effect relative to unsoaked seeds (Fig. 1L).

Table 3

Effect of exogenous application of antioxidants on SVI in fresh and controlled deteriorated (P75 and P25) cabbage seeds.

\begin{tabular}{llll}
\hline Treatments & SVI for fresh seeds & SVI for P75 seeds & SVI for P25 seeds \\
\hline DW & $4923.20 \pm 728.50^{\mathrm{b}}$ & $5414.50 \pm 1099.41^{\mathrm{b}}$ & $2305.20 \pm 1366.14^{\mathrm{b}}$ \\
$\mathrm{AA}(0.2 \mathrm{mM})$ & $4126.50 \pm 648.52^{\mathrm{NS}}$ & $4998.00 \pm 1328.57^{\mathrm{NS}}$ & $3265.50 \pm 966.80^{\mathrm{NS}}$ \\
$\mathrm{AA}(0.4 \mathrm{mM})$ & $3312.00 \pm 361.43^{\mathrm{NS}}$ & $4885.50 \pm 1171.15^{\mathrm{NS}}$ & $3624.00 \pm 1069.05^{\mathrm{NS}}$ \\
$\mathrm{AA}(0.6 \mathrm{mM})$ & $4549.50 \pm 1351.16^{\mathrm{NS}}$ & $5278.50 \pm 1137.44^{\mathrm{NS}}$ & $3084.00 \pm 1569.18^{\mathrm{NS}}$ \\
GA $(0.2 \mathrm{mM})$ & $7793.10 \pm 890.57^{\mathrm{a}}$ & $5741.40 \pm 1318.79^{\mathrm{NS}}$ & $4613.70 \pm 1001.24^{\mathrm{NS}}$ \\
GA $(0.4 \mathrm{mM})$ & $7879.20 \pm 638.02^{\mathrm{a}}$ & $6475.35 \pm 1402.34^{\mathrm{NS}}$ & $3815.70 \pm 1555.03^{\mathrm{NS}}$ \\
GA $(0.6 \mathrm{mM})$ & $7942.20 \pm 965.41^{\mathrm{a}}$ & $6934.20 \pm 1235.94^{\mathrm{NS}}$ & $2879.10 \pm 2453.05^{\mathrm{NS}}$ \\
Glycerol $(0.2 \mathrm{mM})$ & $7679.70 \pm 1024.95^{\mathrm{a}}$ & $8353.80 \pm 1418.06^{\mathrm{NS}}$ & $5798.10 \pm 1185.47^{\mathrm{a}}$ \\
Glycerol $(0.4 \mathrm{mM})$ & $7572.60 \pm 1238.74^{\mathrm{a}}$ & $8225.70 \pm 570.63^{\mathrm{NS}}$ & $5088.30 \pm 2050.79^{\mathrm{a}}$ \\
Glycerol $(0.6 \mathrm{mM})$ & $8162.70 \pm 1161.01^{\mathrm{a}}$ & $6770.40 \pm 1299.03^{\mathrm{NS}}$ & $3192.00 \pm 2313.28^{\mathrm{NS}}$ \\
GSH $(0.2 \mathrm{mM})$ & $3837.60 \pm 669.83^{\mathrm{NS}}$ & $5058.30 \pm 969.49^{\mathrm{NS}}$ & $2328.30 \pm 1038.52^{\mathrm{NS}}$ \\
GSH $(0.4 \mathrm{mM})$ & $3809.00 \pm 513.62^{\mathrm{NS}}$ & $3998.80 \pm 562.45^{\mathrm{NS}}$ & $3069.30 \pm 543.66^{\mathrm{NS}}$ \\
GSH $(0.6 \mathrm{mM})$ & $3641.30 \pm 1013.48^{\mathrm{NS}}$ & $3692.00 \pm 593.13^{\mathrm{NS}}$ & $1592.50 \pm 312.22^{\mathrm{NS}}$ \\
Trolox $(0.2 \mathrm{mM})$ & $7871.60 \pm 1112.36^{\mathrm{a}}$ & $6591.20 \pm 1476.21^{\mathrm{NS}}$ & $4743.20 \pm 1450.51^{\mathrm{NS}}$ \\
Trolox $(0.4 \mathrm{mM})$ & $6551.60 \pm 1341.89^{\mathrm{NS}}$ & $9319.20 \pm 2533.07^{\mathrm{a}}$ & $3062.40 \pm 1655.90^{\mathrm{NS}}$ \\
Trolox $(0.6 \mathrm{mM})$ & $7027.70 \pm 1559.13^{\mathrm{NS}}$ & $7268.80 \pm 1901.68^{\mathrm{NS}}$ & $3711.40 \pm 1465.64^{\mathrm{NS}}$ \\
\hline
\end{tabular}

Values represent mean $\pm \mathrm{SD}(4 \times n=25)$ of control (fresh seeds soaked in deionised water [DW] and all the exogenously applied antioxidants) and seeds at CD levels (P75, P25) where the exogenously applied antioxidants changed seedling vigour index (SVI) significantly relative to DW. Values labelled with different letters are significantly different $(P<0.05$, ANOVA) when compared across soaking treatments within each CD level. NS: not significantly different from value obtained with DW and therefore not considered in statistical comparisons. 
Table 4

Effect of exogenous application of antioxidants on SVI in fresh and controlled deteriorated (P50 and P25) lettuce seeds.

\begin{tabular}{llll}
\hline Treatments & SVI for fresh seeds & SVI for P50 seeds & SVI for P25 seeds \\
\hline DW & $5077.60 \pm 328.17^{\mathrm{NS}}$ & $2799.00 \pm 815.44^{\mathrm{b}}$ & $333.30 \pm 175.13^{\mathrm{b}}$ \\
$\mathrm{AA}(0.2 \mathrm{mM})$ & $6218.60 \pm 650.83^{\mathrm{NS}}$ & $2929.10 \pm 487.93^{\mathrm{NS}}$ & $1736.30 \pm 507.99^{\mathrm{a}}$ \\
$\mathrm{AA}(0.4 \mathrm{mM})$ & $6635.20 \pm 1116.61^{\mathrm{NS}}$ & $3747.40 \pm 762.00^{\mathrm{NS}}$ & $1110.10 \pm 287.88^{\mathrm{NS}}$ \\
$\mathrm{AA}(0.6 \mathrm{mM})$ & $4595.60 \pm 989.48^{\mathrm{NS}}$ & $4153.40 \pm 551.82^{\mathrm{NS}}$ & $809.30 \pm 645.70^{\mathrm{NS}}$ \\
$\mathrm{GA}(0.2 \mathrm{mM})$ & $5160.90 \pm 898.73^{\mathrm{NS}}$ & $3412.10 \pm 569.21^{\mathrm{NS}}$ & $500.00 \pm 847.56^{\mathrm{NS}}$ \\
$\mathrm{GA}(0.4 \mathrm{mM})$ & $6044.90 \pm 490.37^{\mathrm{NS}}$ & $4053.50 \pm 517.51^{\mathrm{NS}}$ & $400.50 \pm 127.43^{\mathrm{NS}}$ \\
$\mathrm{GA}(0.6 \mathrm{mM})$ & $5751.40 \pm 443.09^{\mathrm{NS}}$ & $4548.20 \pm 680.37^{\mathrm{a}}$ & $860.20 \pm 238.97^{\mathrm{NS}}$ \\
Glycerol $(0.2 \mathrm{mM})$ & $5347.60 \pm 911.97^{\mathrm{NS}}$ & $3011.50 \pm 621.05^{\mathrm{NS}}$ & $1432.40 \pm 563.21^{\mathrm{NS}}$ \\
Glycerol $(0.4 \mathrm{mM})$ & $6087.00 \pm 713.95^{\mathrm{NS}}$ & $4209.10 \pm 419.54^{\mathrm{NS}}$ & $1010.10 \pm 838.02^{\mathrm{NS}}$ \\
Glycerol $(0.6 \mathrm{mM})$ & $5760.00 \pm 506.87^{\mathrm{NS}}$ & $4209.60 \pm 455.99^{\mathrm{NS}}$ & $915.20 \pm 359.82^{\mathrm{NS}}$ \\
GSH $(0.2 \mathrm{mM})$ & $5285.00 \pm 941.18^{\mathrm{NS}}$ & $2353.80 \pm 493.35^{\mathrm{NS}}$ & $1195.10 \pm 375.55^{\mathrm{NS}}$ \\
GSH $(0.4 \mathrm{mM})$ & $5299.50 \pm 483.50^{\mathrm{NS}}$ & $3571.60 \pm 311.82^{\mathrm{NS}}$ & $691.00 \pm 260.76^{\mathrm{NS}}$ \\
GSH $(0.6 \mathrm{mM})$ & $4923.00 \pm 538.53^{\mathrm{NS}}$ & $5049.10 \pm 480.58^{\mathrm{NS}}$ & $1746.40 \pm 847.04^{\mathrm{a}}$ \\
Trolox $(0.2 \mathrm{mM})$ & $5820.10 \pm 625.38^{\mathrm{NS}}$ & $3998.60 \pm 610.33^{\mathrm{a}}$ & $1874.80 \pm 352.21^{\mathrm{a}}$ \\
Trolox $(0.4 \mathrm{mM})$ & $5677.70 \pm 1024.38^{\mathrm{NS}}$ & $4666.60 \pm 942.22^{\mathrm{a}}$ & $2334.80 \pm 550.57^{\mathrm{a}}$ \\
Trolox $(0.6 \mathrm{mM})$ & $5214.70 \pm 3179.31^{\mathrm{NS}}$ & $4934.30 \pm 1072.12^{\mathrm{a}}$ & $2344.70 \pm 609.26^{\mathrm{a}}$ \\
\hline
\end{tabular}

Values represent mean $\pm \mathrm{SD}(4 \times n=25)$ of control (fresh seeds soaked in deionised water [DW] and all the exogenously applied antioxidants) and seeds at CD levels (P50, P25) where the exogenously applied antioxidants changed seedling vigour index (SVI) significantly relative to DW. Values labelled with different letters are significantly different $(P<0.05$, ANOVA) when compared across soaking treatments within each CD level. NS: not significantly different from value obtained with DW and therefore not considered in statistical comparisons.

\subsection{Effects of $C D$ and the exogenous application of antioxidants on enzymic antioxidants activities of cabbage and lettuce seeds}

In both species, $\mathrm{CD}$ to $\mathrm{P} 50$ and $\mathrm{P} 25$ led to a significant reduction in catalase (CAT) activity relative to fresh seeds (Table 5). CAT activity was significantly increased in P25 cabbage seed tissues soaked in GA $(0.2 \mathrm{mM})$ and $\mathrm{GSH}(0.6 \mathrm{mM})$ relative to unsoaked and DW-treated P25 seeds (Fig. 2A). CAT activity was also significantly increased in glycerol $(0.6 \mathrm{mM})$ treated P50 lettuce seeds relative to unsoaked P50 seeds but decreased significantly in DW-treated (Fig. 2B). In P25 lettuce seeds, CAT activity was significantly increased when soaked in GSH $(0.6 \mathrm{mM})$ relative to unsoaked seeds but reduced in DW-treated seeds (Fig. 2C).

Controlled deterioration led to a significant reduction in glutathione reductase (GR) activity at P50 and P25 in cabbage seeds and at P75, P50 and P25 in lettuce seeds, relative to fresh seeds (Table 5). The activity of GR was only significantly increased in P25 cabbage seeds soaked in GSH $(0.6 \mathrm{mM})$, relative to unsoaked P25 seeds (Fig. 2D). However, GR activity was significantly increased in P50 (Fig. 2E) and P25 (Fig. 2F) lettuce seeds treated with all beneficial soaking treatments relative to unsoaked seeds; the exogenous antioxidants resulted in a higher GR activity than DW at both CD levels.

In cabbage, $C D$ did not result in a significant change in superoxide dismutase (SOD) activity relative to fresh seeds, but it significantly increased SOD activity in P25 lettuce seeds relative to fresh seeds (Table 5). SOD activity was not significantly influenced by the beneficial soaking treatments in P25 cabbage seeds; rather, it was significantly reduced in DW-treated seeds relative to unsoaked seeds (Fig. 2G). In P50 lettuce, SOD was significantly increased in seeds soaked in GSH $(0.6 \mathrm{mM})$, relative to unsoaked and DW-treated seeds; 0.6 $\mathrm{mM}$ of GA and glycerol resulted in a higher SOD activity than DW (Fig. 2H). SOD activity was significantly increased in P25 lettuce seeds treated with all beneficial soaking treatments, relative to unsoaked seeds (Fig. 2I).

\subsection{Effects of $C D$ and the exogenous application of antioxidants on germination-related enzymes in cabbage and lettuce seeds}

In both species, $\mathrm{CD}$ led to a significant reduction in $\alpha$-amylase activity relative to fresh seeds, but these differences were only significant at P25 (Table 5). However, $\alpha$-amylase activity increased significantly in P25 cabbage seeds treated with glycerol $(0.4 \mathrm{mM})$ relative to unsoaked seeds; trolox $(0.2 \mathrm{mM})$ resulted in a higher $\alpha$-amylase activity than DW (Fig. 3A). In P50 lettuce seeds, $\alpha$-amylase activity was not significantly influenced by the beneficial soaking treatments (Fig. 3B), but the enzyme's activity was significantly increased in P25 lettuce seeds soaked in GSH $(0.6 \mathrm{mM})$ and trolox (0.6 mM), relative to unsoaked and DW-treated seeds (Fig. 3C).

Controlled deterioration led to a significant reduction in $\beta-1,3-$ glucanase activity in cabbage seeds at P50 and P25 and in lettuce seeds at P25, compared with fresh seeds (Table 5 ). $\beta$-1,3-glucanase activity increased significantly in P25 cabbage seeds exposed to exogenous antioxidants, but those treated with DW had a significantly reduced activity relative to unsoaked seeds (Fig. 3D). However, $\beta$-1,3-glucanase activity was significantly increased in P50 lettuce seeds treated with all beneficial soaking treatments relative to unsoaked seeds (Fig. 3E). Similarly, $\beta$-1,3-glucanase activity increased significantly in P25 lettuce seeds treated with all beneficial soaking treatments relative to unsoaked seeds (Fig. 3F). The exogenous antioxidants resulted in higher $\beta$-1,3-glucanase activity than DW in both P50 and P25 lettuce seeds.

\section{Discussion}

Studies that have employed CD to investigate the phenomenon of seed ageing have shown that even when moisture level and temperature are controlled for, the rate of vigour and viability loss varies across species (Berjak and Villiers, 1972; Merritt et al., 2003; Shaban, 2013). This variation is a function of the ability of seeds of different species to resist degradative changes through protective mechanisms to varying degrees (Shaban, 2013).

In the present study, $C D$ led to the loss of vigour and viability in both cabbage and lettuce seeds; however, this decline occurred at different rates in both species. Below P75, viability declined slower in cabbage seeds than in those of lettuce. With CD, SVI in cabbage seeds was less severely compromised than in lettuce seeds (Tables 3 and 4, respectively). Moreover, there was no significant change in CJD and 4-HNE levels and SOD activity in cabbage seeds but in lettuce seeds (Table 5). However, even though cabbage seeds exhibited lower levels of viability loss and oxidative stress when deteriorated, they produced much more abnormal seedlings than lettuce seeds (Table S1). These differences suggest that the mechanisms of seed deterioration 


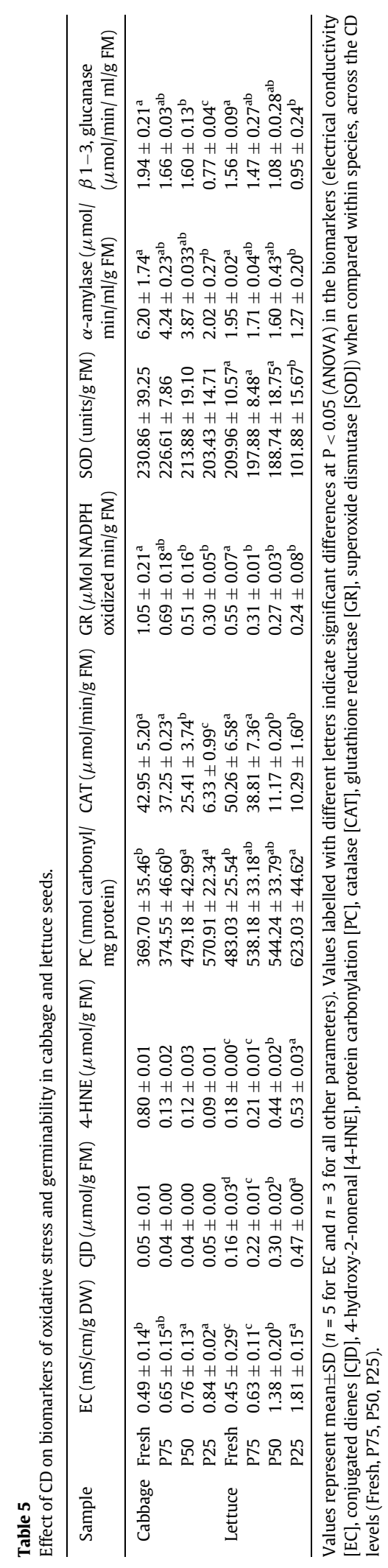

in both species may not be the same. While CD led to oxidative stress in lettuce seeds, it appears to affect developmental processes in cabbage seeds. Nevertheless, CD increased the frequency of abnormal seedling production in both species, and this occurred in the soaking treatments as well (Table S1). A rising proportion of abnormal seedling production in seed lots that are still viable and capable of producing a high germination capacity is a symptom of deterioration (Matthews, 1985). A previous study on the effect of exogenous application of antioxidants prior to the ageing of sunflower seed showed an increased number of abnormal seedlings (Draganić and Lekić, 2012). A gradual loss of seed vigour resulting in the eventual loss of viability has been reported to characterise seed deterioration (Argerich and Bradford, 1989; Lehner et al., 2008). This may be attributed to various factors including deterioration-induced cellular, chemical and metabolic modifications (Bailly et al., 2008; Boniecka et al., 2019). Uncontrolled ROS accumulation during hydration of aged seeds inhibits radicle protrusion (germination) or causes seeds to develop into abnormal seedlings (Bailly et al., 2008). El-Maarouf-Bouteau et al. (2011) proposed the involvement of programmed cell death, mitochondria dysfunction, DNA modification and oxidative burst in seed deterioration.

Importantly, in the present study, selected (beneficial) soaking treatments improved normal seedling production of cabbage and lettuce seeds but not necessarily at the same concentrations and CD levels. Glycerol, GSH and trolox, for instance, increased normal seedling production in both species at P25 while AA, glycerol and GSH increased normal seedling production at P50 and P25 in lettuce seeds (Tables 1 and 2). In lettuce, $0.6 \mathrm{mM}$ of all exogenous antioxidants significantly increased normal seedling production but not necessarily at the same CD levels. Additionally, GA was effective in both species but at different concentrations and CD levels. In previous studies, exogenous application of antioxidants such as AA enhanced viability in aged seeds of Elymus sibiricus (Yan et al., 2015) and maximum growth and yield of salt-stressed Ablemoschus esculentus seeds (Raza et al., 2013). Increased level of endogenous glycerol through seed soaking treatments is speculated to have a protective effect on plants in extreme environmental conditions (Ali et al., 2008; Tiryaki and Buyukcingil, 2009). The improvement of normal seedling production induced by the beneficial soaking treatments identified here may be related to the suggested role of exogenous antioxidants in stimulating and activating plant endogenous antioxidant contents which are conjectured to be contingent upon NADPH (reductant) given off as carbon flux product via the pentose phosphate pathway (Burguieres et al., 2007). Under stress conditions, the exogenously supplied antioxidants possibly function in the indirect stimulation of the biosynthesis of growth-promoting substances such as amino acids (e.g. proline) associated with pentose phosphate pathway activity, which is a source of precursors of sugar phosphate needed for the synthesis of phenolics (Burguieres et al., 2007). Phenolics are known for their inherent potent antioxidant properties (Ghasemzadeh and Ghasemzadeh, 2011).

The beneficial soaking treatments also improved SVI of cabbage and lettuce seeds but not necessarily at the same concentrations and CD levels (Tables 3 and 4, respectively). The application of GA and trolox, for instance, improved SVI in both species but at varying concentrations and different CD levels. Glycerol improved SVI in Fresh and P25 cabbage seeds, while AA and GSH improved SVI in P25 lettuce seeds only. The effect of the beneficial soaking treatments on SVI was, however, not observed in P50 cabbage seeds, and fresh and P75 lettuce seeds. The effects of antioxidants on plant growth extend to several physiological processes which include the regulation of plant growth, cell differentiation and metabolism (Shao et al., 2008). Havas (1935) and Draganić and Lekić (2012) reported accelerated seedling growth and improved shoot and root length as a result of antioxidant application. Exogenous antioxidant-linked improvement of seedling growth response may be related to the role of antioxidants in the 


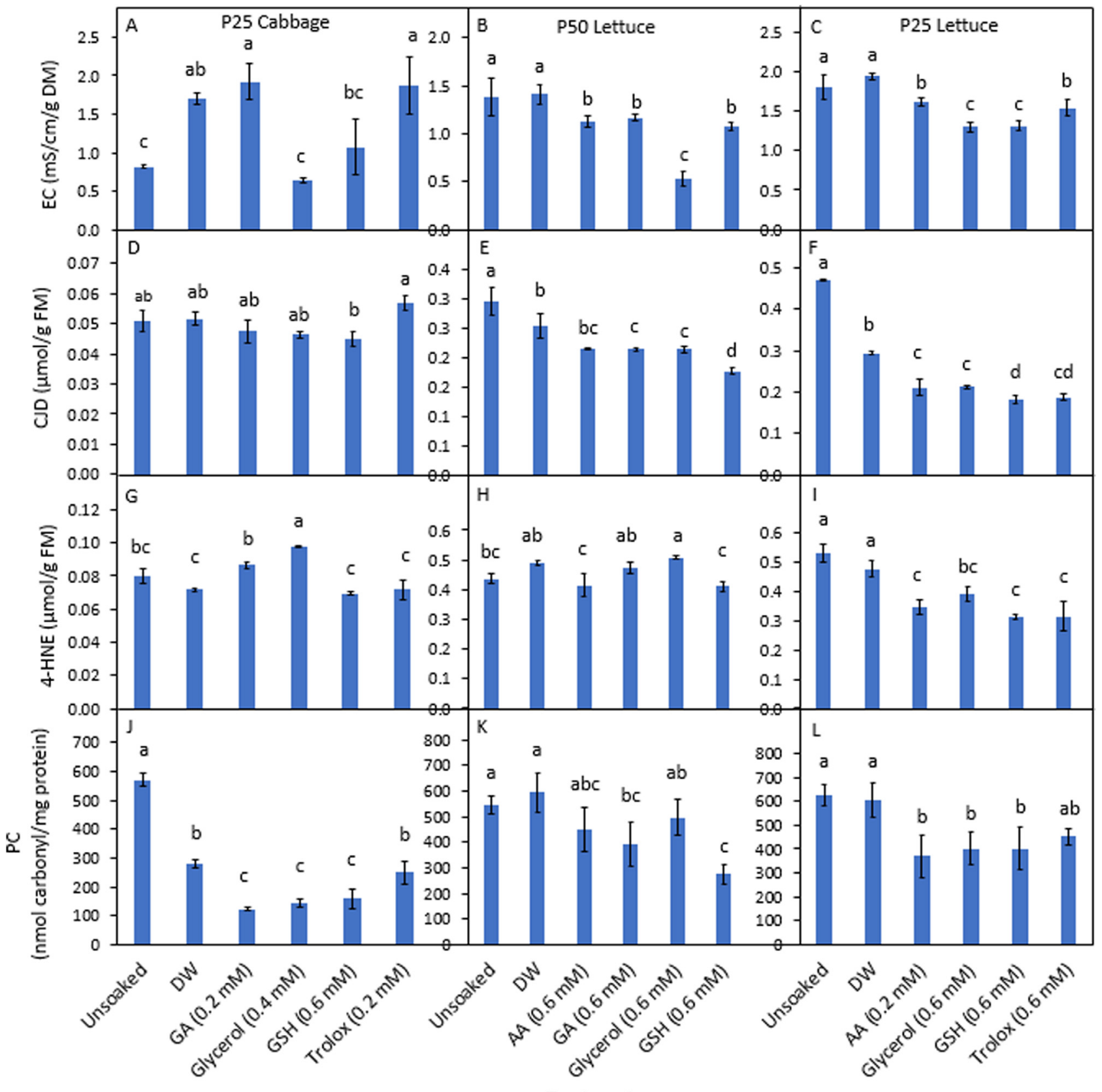

Treatment

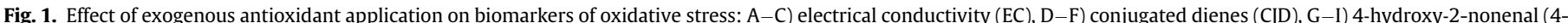

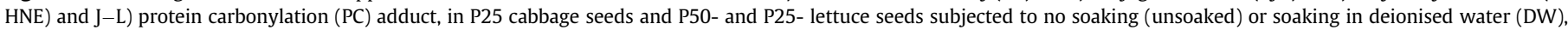

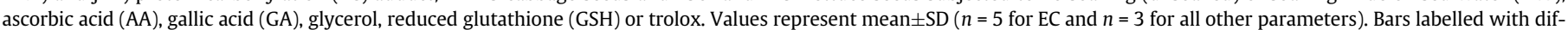
ferent letters indicate significant differences at $\mathrm{P}<0.05$ (ANOVA).

modification of processes, including cell division and elongation (Shao et al., 2008). They may be stimulating the synthesis of endogenous antioxidants (Burguieres et al., 2007) which in influencing plant growth regulators, modulate growth (Pastori et al., 2003).

The present study demonstrates that $\mathrm{CD}$ led to the loss of membrane integrity, as measured by EC, in cabbage and lettuce seeds at P50 and P25 (Table 5). Although the application of exogenous antioxidants has been reported to extenuate the injurious effect of stress in several species (Ahmad et al., 2012; Ejaz et al., 2012; Raza et al., 2013), the beneficial soaking treatments (mentioned above) did not reduce EC in P25 cabbage seeds (Fig. 1A). In lettuce seeds, however, the beneficial soaking treatments $(0.6 \mathrm{mM}$ of $\mathrm{AA}, \mathrm{GA}$, glycerol and GSH in P50; 0.6 mM of AA, glycerol, GSH and trolox in P25) resulted in a marked reduction in EC (Fig. 1B and 1C, respectively). The free movement of solutes and water, an indicator of cell membrane permeability, resulting from stress induced modifications such as lipid peroxidation and the disappearance of membrane phospholipids from plant tissues have been attributed to seed deterioration (Simon, 1974; Mira et al., 2011) in terms of loss of vigour and viability (Bedi et al., 2006; Sahu et al., 2017). Reduction of EC levels by the beneficial soaking treatments is indicative of their potentiality for promoting the retention of membrane integrity during $C D$ in lettuce seeds. This again points to the potential disparity in the mechanisms of ageing in both species. For leakage of solutes to be suppressed, membranes need to regain their integrity of bilayer conformation (Simon, 1974). Chain-breaking antioxidants, particularly AA, tocopherols, and GSH can directly "repair" ROS attack on lipid structures, thereby defending 


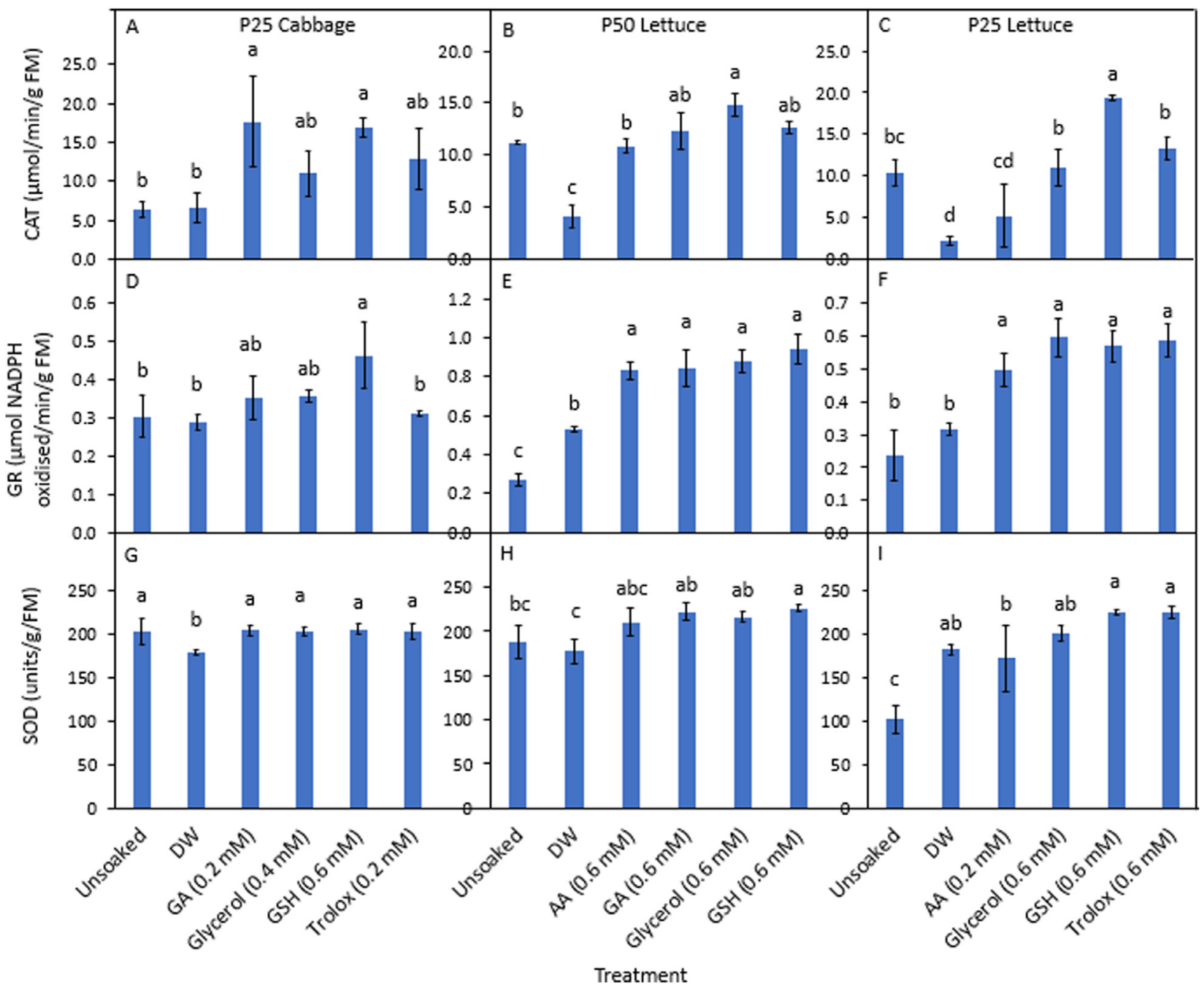

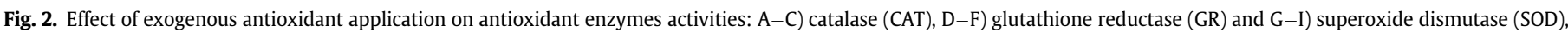

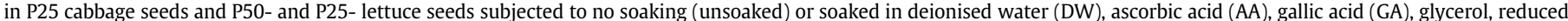

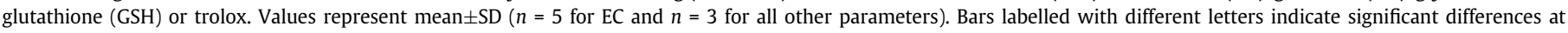
$\mathrm{P}<0.05$ (ANOVA).

against membrane injury (Buettner, 1993); this may have been the case in deteriorated lettuce seeds here.

Seed deterioration has been previously reported to be characterised by the accumulation of lipid peroxidation products in various species (Acer Platanoides, Pukacka, 1991; sunflower seeds, Kibinza et al., 2006; Zygophyllum xanthoxylon, Li et al., 2008). On the contrary, other studies, have shown that lipid peroxidation, as measured by its products, was not related to seed deterioration in Zea mays (Lin and Pearce, 1990), wheat grains (Lehner et al., 2008), and Brassicaceae species (Mira et al., 2011). As alluded to earlier, CD led to little or no accumulation of lipid peroxidation products (CJD and 4-HNE) in cabbage seeds while CDd lettuce seeds exhibited heightened levels of CJD and 4-HNE (Table 5). In P50 and P25 lettuce seeds, CJD levels were reduced by all beneficial soaking treatments (Fig. $1 \mathrm{E}$ and $1 \mathrm{~F}$, respectively), but this was not the case for 4-HNE as it was only in P25 lettuce seeds that 4-HNE levels were reduced by the exogenous antioxidants (Fig. 1I). Mira et al. (2011) showed that though electrolyte conductivity increased with seed deterioration, no accumulation of malondialdehyde (MDA) was recorded in ageing processes of four wild Brassicaceae species. The present results indicate that there are uncertainties about what mechanism(s) of membrane damage occur in deteriorated cabbage seeds as ageing was not accompanied by the accumulation of lipid peroxides despite the increase in electrolyte leakage; other researchers have made similar observations (E.A. Golovina, personal communication, April 30, 2019). Additionally, Lehner et al. (2008) reported that there was no change in MDA during ageing in wheat grains and thus opined that lipid peroxidation was not necessary for ageing to occur. The beneficial soaking treatments most likely reduced lipid peroxidation events in P50 and P25 lettuce seeds by scavenging ROS and/or enhancing the antioxidant defence system, leading to improved normal seedling production and SVI. Antioxidants such as tocopherol, a primary lipophilic antioxidant, and AA, a hydrophilic antioxidant, work together to defend lipids from peroxidative reactions (Buettner, 1993). These antioxidants were also beneficial in lettuce seeds.

Increased $\mathrm{PC}$ is an indication of oxidative damage to protein and did characterise CD in P50 and P25 cabbage seeds and P25 lettuce seeds (Table 5). All beneficial soaking treatments were effective in reducing PC levels in P25 cabbage seeds (Fig. 1J). In both cabbage and lettuce seeds, GSH $(0.6 \mathrm{mM})$ reduced PC formation while DW was effective at doing this in P25 cabbage seeds only. In P50 lettuce seeds, $0.6 \mathrm{mM} \mathrm{GA}$ was effective at reducing PC level, while $0.2 \mathrm{mM} \mathrm{AA}$ and $0.6 \mathrm{mM}$ of glycerol also brought about a marked reduction in the carbonyl derivatives in P25 lettuce seeds (Fig. $1 \mathrm{~K}$ and $1 \mathrm{~L}$, respectively). In a study on Arabidopsis thaliana seeds, CD substantially raised PC levels (Rajjou et al., 2008) and those authors opined that this might 


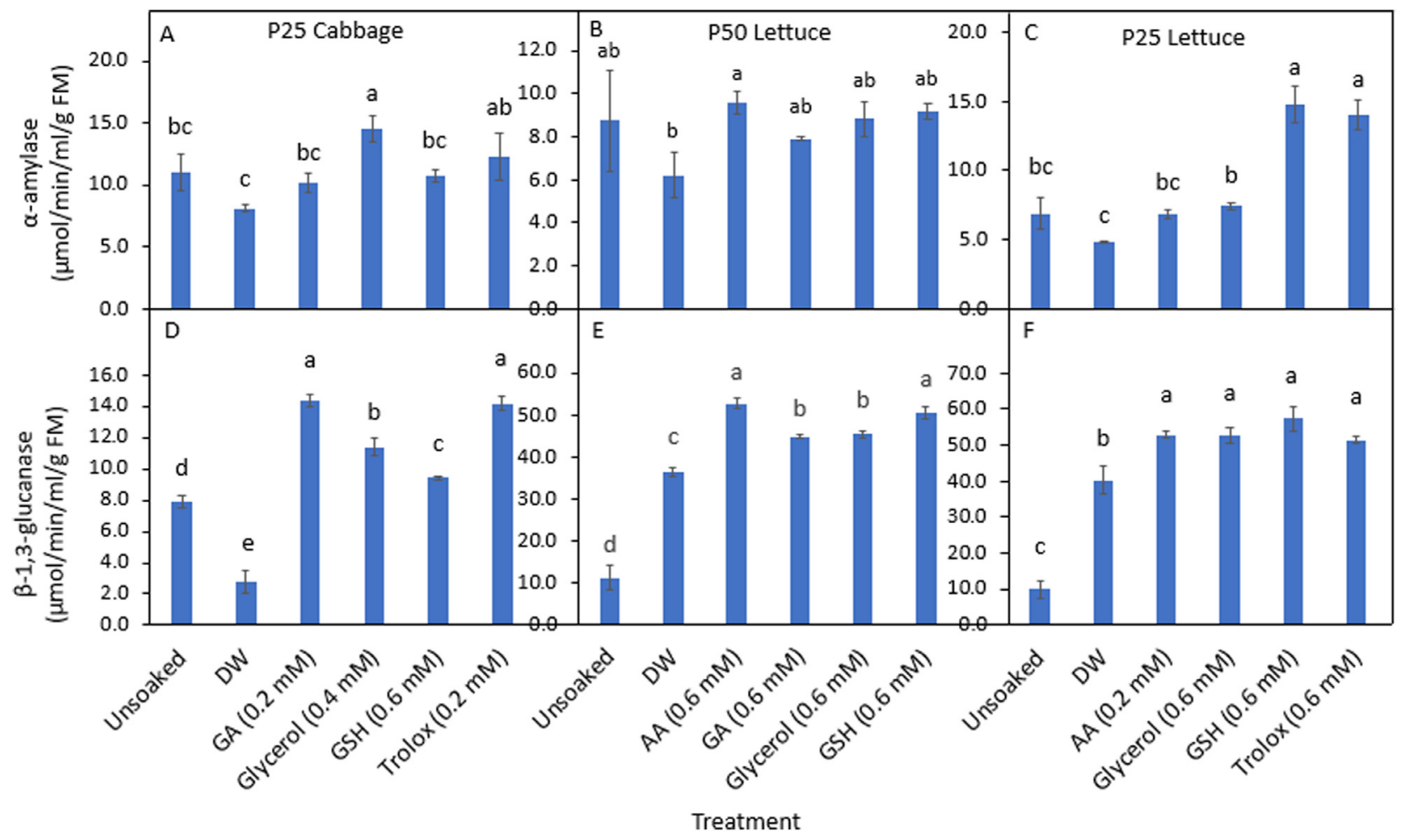

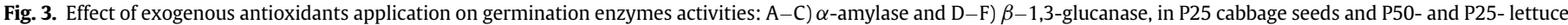

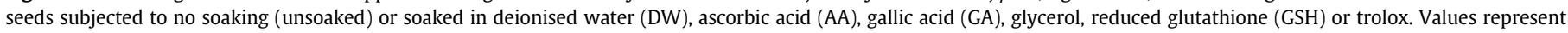
mean $\pm \mathrm{SD}$ ( $n=5$ for EC and $n=3$ for all other parameters). Bars labelled with different letters indicate significant differences at $\mathrm{P}<0.05$ (ANOVA).

cause loss of functional properties of proteins and enzymes or heightened seed susceptibility to proteolysis. They suggested further that loss of germinative vigour may be attributed to changes in seed protein and the inability of deteriorated seeds to display a normal proteome while germinating. Kalemba and Pukacka (2014), Sahu et al. (2017) and Yin et al. (2017) similarly implicated carbonylation of proteins in oxidative stress damaged seeds of Fagus sylvatica, Pongamia pinnata and Oryza sativa, respectively. On the contrary, Golovina et al. (1997a, 1997b) reported the conservation of proteins during long term seed storage of several other orthodox species, including Brassica napus. From results presented here, loss of seed viability and vigour with $C D$ in both species was related to increased protein oxidation, and the benefits of soaking treatments appear to have been partly based on the mitigation thereof. Proteins may be a major ROS target due to their rapid reactivity with several reactive oxidants, in addition to their presence in large quantity in cells, plasma, and nearly all tissues (Hawkins et al., 2009).

An efficient defence system capable of quelling high levels of reactive oxidants is essential for seed survival and recovery from deterioration. The results of the present work show that $C D$ was accompanied by a progressive decline in the antioxidant capacity (specifically CAT activity at P50 and P25) in both cabbage and lettuce seeds (Table 5). The activity of CAT was, however, increased by GSH $(0.6 \mathrm{mM})$ in both species at P25 (Fig. 2A and 2C), while glycerol (0.6 $\mathrm{mM})$ and $\mathrm{GA}(0.2 \mathrm{mM})$ induced a substantial rise in CAT activity in P50 (Fig. 2B) and P25 (Fig. 2C) lettuce seeds, respectively. A decline in CAT activity was reported for Sesamum indicum seeds (Tabatabaei, 2013) and was cited as one of the reasons for the loss of viability in aged Triticum aestivum grains (Lehner et al., 2008) and Helianthus annuus seeds (Kibinza et al., 2006). CAT has been described as a major enzyme involved in the recovery of seeds from deterioration (Kibinza et al., 2011). Like peroxidase (POX), CAT is mainly involved in the hydrolysis of hydrogen peroxide $\left(\mathrm{H}_{2} \mathrm{O}_{2}\right)$, a critically toxic by-product of oxidative metabolism, to water and oxygen (Kibinza et al., 2011; Sahu et al., 2017).

Controlled deterioration also led to a significant reduction in GR activity in P50 and P25 cabbage seeds, and in P75, P50 and P25 lettuce seeds (Table 5). In P25 cabbage seeds, only GSH (0.6 mM) caused a marked rise in GR activity (Fig. 2D), while all beneficial soaking treatments enhanced GR activity in P50 and P25 lettuce seeds (Fig. 2E and $2 \mathrm{~F}$, respectively). Previous studies have documented that seed deterioration was characterised by reduced GR activity in Citrullus vulgaris (Hsu and Sung, 1997), Gossypium hirsutum (Goel and Sheoran, 2003) and Helianthus annuus (Kibinza et al., 2006) seeds. The role of GR includes regeneration of GSH, a substance that itself is involved in removing ROS, from oxidised glutathione (GSSG) to maintain the redox status of glutathione (Kibinza et al., 2011). The GSH protects -SH groups in enzymes and structural proteins against oxidation by either scavenging oxidants or mending -SH groups through GSH-disulfide exchange reaction. The GSSG produced is then rapidly reduced by GR (Esterbauer and Grill, 1978). Heightening endogenous antioxidants levels and enhancing the activity of antioxidative enzymes, such as GR, may be a strategy of plant cells to limit harmful peroxidation (Schmidt and Kunert, 1986).

Controlled deterioration did not influence SOD activity of cabbage seeds but caused a significant reduction in the enzyme's activity in P25 lettuce seeds (Table 5). In P25 cabbage seeds, SOD activity was not enhanced by the soaking treatments (Fig. 2G) but was enhanced by GSH ( $0.6 \mathrm{mM}$ ) in P50 lettuce seeds (Fig. $2 \mathrm{H}$ ), and by all beneficial soaking treatments in P25 lettuce seeds (Fig. 2I). Ageing-induced loss of seed viability has been demonstrated to involve reduced SOD activity in several plant species such as Gossypium hirsutum (Goel and Sheoran, 2003), H. annuus (Kibinza et al., 2006) and T. aestivum (Lehner et al., 2008). SOD is known to be directly responsible for the dismutation of superoxide anion radical $\left(\mathrm{O}_{2}\right)$ by removing oxygen radicals and forming $\mathrm{H}_{2} \mathrm{O}_{2}$ (Saed-Moucheshi et al., 2014). The longevity of seeds in storage is dependant on their ability to produce and 
employ antioxidative enzymes for the scavenging of surplus reactive oxidants (Shaban, 2013; Sahu et al., 2017). Enhanced activity of CAT in Ablemoschus esculentus (Raza et al., 2013), GR and SOD in H. annuus (Bailly et al., 1998, 2000; Kibinza et al., 2011), CAT and SOD in P. sativum (Burguieres et al., 2007) were linked with the recovery of seed vigour. Collectively, the present results show that certain exogenously applied antioxidants can enhance the activities of endogenous enzymic antioxidants, and subsequent seedling production and SVI, but the effects appear to be enzyme and treatment specific.

Controlled deterioration led to a reduction in the $\alpha$-amylase activity of cabbage and lettuce seeds at P25 (Table 5). Glycerol (0.4 mM) induced hydrolysis of starch by increasing $\alpha$-amylase activity in P25 cabbage (Fig. 3A). The activity of $\alpha$-amylase was not influenced by the soaking treatments in P50 lettuce seeds (Fig. 3B) but was heightened by GSH $(0.6 \mathrm{mM})$ and trolox $(0.6 \mathrm{mM})$ in P25 lettuce seeds (Fig. 3C). Reduced amylase activity was reported in aged wheat grains (Livesley and Bray, 1991; Das and Sen-Mandi, 1992) and Brassica campestris (Bedi et al., 2006). Loss of viability may be linked to seed inability to adequately produce $\alpha$-amylase, which in turn is presumed to be due to ageing-induced inadequacy of plant growth regulators such as gibberellins (Petruzzelli and Taranto, 1990), and other ageing-related impairments (Ganguli and Sen-Mandi, 1993). Additionally, $\mathrm{CD}$ resulted in a significant decline in $\beta-1,3$-glucanase activity of P50 and P25 cabbage and P25 lettuce (Table 5). The exogenous antioxidants enhanced $\beta$-1,3-glucanase activity in P25 cabbage seeds (Fig. 3D) while all beneficial soaking treatments enhanced its activity in both P50 and P25 lettuce seeds (Fig. 3E and 3F, respectively). Increased $\beta-1,3$-glucanase activity related to increased seed germination of Origanum vulgare (Farashah et al., 2011). The present results suggest that treatment of aged cabbage and lettuce seeds with antioxidants can enhance seedling production and SVI by promoting the activity of key germination enzymes.

\section{Concluding remarks and recommendations}

Controlled deterioration resulted in the loss of vigour and viability and increased frequency of abnormal seedlings in both cabbage and lettuce seeds, but the mechanisms of ageing appear to differ between species. While CD was accompanied by a rise in EC and PC, and a decline in CAT, GR, SOD, $\alpha$-amylase and $\beta$-1,3-glucanase activities in both species, only lettuce seeds exhibited a rise in lipid peroxidation products (CJD and 4-HNE).

Out of the five antioxidants applied to seeds, four (GA, glycerol, GSH and trolox) were beneficial in cabbage; all five were beneficial in lettuce, and four were beneficial in both species, in terms of improving viability in CDd seeds. The beneficial effects of these antioxidants appear to be based on mitigating the effects of physical and biochemical lesions that accompany ageing in seeds. For instance, in lettuce seeds, EC and lipid peroxidation were reduced by the application of AA, GA, glycerol, GSH and trolox. Protein oxidation was reduced by GA, glycerol and GSH in both species. Antioxidant and germination enzymes activities were enhanced by GA, glycerol, GSH, and trolox in cabbage seeds and AA, GA, glycerol, GSH, and trolox in lettuce seeds. Interestingly, DW also reduced PC in cabbage seeds and lipid peroxidation in lettuce seeds, and enhanced antioxidant and germination enzymes activities in lettuce seeds.

Oxidative stress appears to be a major contributor to seed viability loss during ageing in both cabbage and lettuce; whilst the lesions brought about by oxidative damage may not be the same in both species, treatment with AA, glycerol, GSH and trolox can improve vigour and viability in their aged seeds.

Further investigations on the lesions imposed by ageing at the molecular level (e.g. via protein profiles and, assessment of DNA integrity) and the possible influence of exogenous antioxidants on obviating this damage are recommended. Furthermore, the role of exogenous antioxidant application, especially glycerol and GSH, on epigenetic changes associated with seed deterioration and recovery are worth pursuing.

\section{Declaration of Competing Interest}

The authors declare no conflict of interest.

\section{Funding}

This work was funded by research grant by the National Research Foundation of South Africa to N.W. Pammenter (grant number CPRR13092145823). The APC was partially funded by the University of KwaZulu-Natal, South Africa.

\section{Author Contributions}

Ademola Adetunji did the experimental work, analysed the data and wrote the original manuscript as supervised by Sershen, Boby Verghese and Norman Pammenter.

\section{Supplementary materials}

Supplementary material associated with this article can be found in the online version at doi:10.1016/j.sajb.2020.10.001.

\section{References}

Ab Hamid, S.S., Zahari, N.K., Yusof, N., Hassan, A., 2014. Scanning electron microscopic assessment on surface morphology of preserved human amniotic membrane after gamma sterilisation. Cell Tissue Bank 15, 15-24. https://doi.org/10.1007/s10561012-9353-X.

Abdul-Baki, A., Aref, Anderson, D., James, 1973. Vigor determination in soybean seed by multiple criteria. Crop science 13 (6), 630-633.

Adetunji, E., Ademola, Sershen, Varghese, Boby, Pammenter, W., Nroman, 2020. Effects of inorganic salt solutions on vigour, viability, oxidative metabolism and germination enzymes in aged cabbage and lettuce seeds. Plants 9 (9), 1164. https://doi.org/ 10.3390/plants9091164.

Afzal, I., Basra, S.M.A., Hameed, A., Farooq, M., 2006. Physiological enhancements for alleviation of salt stress in wheat. Pakistan J. Bot. 38, 1649-1659.

Ahmad, I., Khaliq, T., Ahmad, A., Basra, S.M.A., Hasnain, Z., Ali, A., 2012. Effect of seed priming with ascorbic acid, salicylic acid and hydrogen peroxide on emergence, vigor and antioxidant activities of maize. African J. Biotechnol. 11, 1127-1132.

Ali, R.M., Elfeky, S.S., Abbas, H., 2008. Response of salt stressed Ricinus communis L. To exogenous application of glycerol and/or aspartic acid. J. Biol. Sci. 8, 171-175. https://doi.org/10.3923/jbs.2008.171.175.

Al-maskri, Ahmed, Kharr, M., Mumtaz, Ai-mantheriand, Omar, Al-habs, Khamis, 2002. Effect of accelerated aging on lipid peroxidation, leakage and seedling vigor (RGR) in cucumber (Cucumis sativus L.) seeds. Pakistan journal of agricultural sciences 39 (4), 303-337.

Amjad, M., Ziaf, K., Iqbal, Q., Ahmad, I., Atif, M., Saqib, Z.A., 2007. Effect of seed priming on seed vigour and salt tolerance in hot pepper. Agriculture 44, 408-416.

Argerich, C.A., Bradford, K.J., 1989. The effects of priming and ageing on seed vigour in tomato. J. Exp. Bot. 40, 599-607. https://doi.org/10.1093/jxb/40.5.599.

Augustyniak, E., Adam, A., Wojdyla, K., Rogowska-Wrzesinska, A., Willetts, R., Korkmaz, A., Atalay, M., Weber, D., Grune, T., Borsa, C., Gradinaru, D., Chand Bollineni, R., Fedorova, M., Griffiths, H.R., 2015. Validation of protein carbonyl measurement: a multi-centre study. Redox Biol 4, 149-157. https://doi.org/ 10.1016/j.redox.2014.12.014.

Bailly, C., 2004. Active oxygen species and antioxidants in seed biology. Seed Sci. Res. 14, 93-107. https://doi.org/10.1079/SSR2004159.

Bailly, C., Benamar, A., Corbineau, F., Come, D., 1998. Free radical scavenging as affected by accelerated ageing and subsequent priming in sunflower seeds. Physiol. Plant. 104, 646-652. https://doi.org/10.1034/j.1399-3054.1998.1040418.x.

Bailly, C., Benamar, A., Corbineau, F., Côme, D., 2000. Antioxidant systems in sunflower (Helianthus annuus L.) seeds as affected by priming. Seed Sci. Res. 10, 35-42. https://doi.org/10.1017/S0960258500000040.

Bailly, C., El-Maarouf-Bouteau, H., Corbineau, F., 2008. From intracellular signaling networks to cell death: the dual role of reactive oxygen species in seed physiology. Comptes Rendus - Biol. 331, 806-814. https://doi.org/10.1016/j.crvi.2008.07.022.

Baker, J.E., 1991. Purification and partial characterisation of $\alpha$-amylase allozymes from the lesser grain borer, Rhyzopertha dominica. Insect Biochem. 21, 303-311. https://doi.org/10.1016/0020-1790(91)90020-F.

Basra, S.M.A., Ahmad, N., Khan, M.M., Iqbal, N., Cheema, M.A., 2003. Assessment of cottonseed deterioration during accelerated ageing. Seed Sci. Technol. 31, 531-540. https://doi.org/10.15258/sst.2003.31.3.02.

Beauchamp, C., Fridovich, I., 1971. Superoxide dismutase: improved assays and an assay applicable to acrylamide gels. Anal. Biochem. 44, 276-287. https://doi.org/ 10.1016/0003-2697(71)90370-8. 
Bedi, S., Kaur, R., Sital, J.S., Kaur, J., 2006. Artificial ageing of Brassica seeds of different maturity levels. Seed Sci. Technol. 34, 287-296. https://doi.org/10.15258/ sst.2006.34.2.04

Benamar, A., Tallon, C., Macherel, D., 2003. Membrane integrity and oxidative properties of mitochondria isolated from imbibing pea seeds after priming or accelerated ageing. Seed Sci. Res. 13, 35-45. https://doi.org/10.1079/ssr2002122.

Berjak, P., Pammenter, N.W., 2013. implications of the lack of desiccation tolerance in recalcitrant seeds. Front. Plant Sci. 5, 1-9. https://doi.org/10.3389/fpls.2014.00123.

Berjak, P., Villiers, T.A., 1972. Ageing in plant embryos. New Phytol. 71, 1069-1074. https://doi.org/10.1111/j.1469-8137.1972.tb01984.x.

Bernfeld, P., 1955. Amylases, alpha and $\beta$. Methods Enzymol. I I 149-158. https://doi. org/10.1016/0076-6879(55)01021-5.

Biswas, P.K., Devi, A., Roy, P.K., Paul, K.B., 1978. Enzyme activity in dormant and nondormant large crabgrass (Digitaria sanguinalis) seeds following hydration. Weed Sci. 26, 90-93. https://doi.org/10.1017/S0043174500032744.

Boniecka, J., Kotowicz, K., Skrzypek, E., Dziurka, K., Rewers, M., Jedrzejczyk, I., Wilmowicz, E., Berdychowska, J., Dabrowska, G.B., 2019. Potential biochemical, genetic and molecular markers of deterioration advancement in seeds of oilseed rape (Brassica napus L.). Ind. Crops Prod. 130, 478-490. https://doi.org/10.1016/J. INDCROP.2018.12.098.

Bradford, Marion, M., 1976. A rapid and sensitive method for the quantitation of microgram quantities of protein utilizing the principle of protein-dye binding. Analytical Biochemistry 72 (1), 248-254.

Buettner, G.R., 1993. The pecking order of free radicals and antioxidants: lipid peroxidation, $\alpha$-tocopherol, and ascorbate. Arch. Biochem. Biophys. 300, 535-543. https://doi.org/10.1006/abbi.1993.1074.

Burguieres, E., McCue, P., Kwon, Y.I., Shetty, K., 2007. Effect of vitamin C and folic acid on seed vigour response and phenolic-linked antioxidant activity. Bioresour. Technol. 98, 1393-1404. https://doi.org/10.1016/j.biortech.2006.05.046.

Celestino, K.R.S., Cunha, R.B., Felix, C.R., 2006. Characterisation of a $\beta$-glucanase produced by Rhizopus microsporus var. microsporus, and its potential for application in the brewing industry. BMC Biochem. 7, 23. https://doi.org/10.1186/1471-20917-23.

Chandra, J., Sershen, Varghese, B., Keshavkant, S., 2019. The potential of ROS inhibitors and hydrated storage in improving the storability of recalcitrant Madhuca latifolia seeds. Seed Sci. Technol. 47, 33-45. https://doi.org/10.15258/sst.2019.47.1.04.

Choudhury, F.K., Rivero, R.M., Blumwald, E., Mittler, R., 2017. Reactive oxygen species, abiotic stress and stress combination. Plant J 90, 856-867. https://doi.org/10.1111/ tpj.13299.

Claiborne, A., 1985. Catalase activity. In: Greenwald, E.A. (Ed.), CRC Handbook of Methods for Oxygen Radical Research. CRC Press, Boca Raton, FL, pp. 283-284.

Das, G., Sen-Mandi, S., 1992. Scutellar amylase activity in naturally aged and accelerated aged wheat seeds. Ann. Bot. 69, 497-501. https://doi.org/10.1093/oxfordjournals.aob.a088378.

Dell'Aquila, A., 1994. Wheat seed ageing and embryo protein degradation. Seed Sci. Res. 4, 293-298. https://doi.org/10.1017/S0960258500002324.

Demir, I., Mavi, K., 2008. Controlled deterioration and accelerated aging tests to estimate the relative storage potential of cucurbit seed lots. HortScience 43, 15441548.

Draganić, I., Lekić, S., 2012. Seed priming with antioxidants improves sunflower seed germination and seedling growth under unfavorable germination conditions. Turkish J. Agric. For. 36, 421-428. https://doi.org/10.3906/tar-1110-16.

E.A. Golovina, personal communication, April 30, 2019, 2019. E.A. Golovina, personal communication, April 30, 2019.

Ejaz, B., Sajid, Z.A., Aftab, F., 2012. Effect of exogenous application of ascorbic acid on antioxidant enzyme activities, proline contents, and growth parameters of Saccharum spp. hybrid cv. HSF-240 under salt stress. Turkish J. Biol. 36, 630-640. https:// doi.org/10.3906/biy-1201-37.

El-Maarouf-Bouteau, H., Mazuy, C., Corbineau, F., Bailly, C., 2011. DNA alteration and programmed cell death during ageing of sunflower seed. J. Exp. Bot. 62, 50035011. https://doi.org/10.1093/jxb/err198.

Esterbauer, H., Grill, D., 1978. Seasonal variation of glutathione and glutathione reductase in needles of picea abies. Plant Physiol. 61, 119-121. https://doi.org/10.1104/ pp.61.1.119.

Farashah, D.H., Afshari, T.R., Sharifzadeh, F., Chavoshinasab, S., 2011. Germination improvement and $\alpha$-amylase and $\beta$-1,3-glucanase activity in dormant and nondormant seeds of Oregano (Origanum vulgare). Aust. J. Crop Sci. 5, 421-427.

Farrant, J.M., Bailly, C., Leymarie, J., Hamman, B., Come, D., Corbineau, F., 2004. Wheat seedlings as a model to understand desiccation tolerance and sensitivity. Physiol. Plant. 120, 563-574. https://doi.org/10.1111/j.0031-9317.2004.0281.x.

Ferguson, J.M., TeKrony, D.M., Egli, D.B., 1990. Changes during early seed and axes deterioration: I. seed quality and mitochondrial respiration. Crop Sci. 30, 175-179. https://doi.org/10.2135/cropsci1990.0011183x003000010038x.

Ganguli, S., Sen-Mandi, S., 1993. Effects of ageing on amylase activity and scutellar cell structure during imbibition in wheat seed. Ann. Bot. 71, 411-416.

Ghasemzadeh, A., Ghasemzadeh, N., 2011. Flavonoids and phenolic acids: role and biochemical activity in plants and human. J. Med. Plant Res. 5, 6697-6703. https://doi. org/10.5897/JMPR11.1404.

Goel, A., Sheoran, I.S., 2003. Lipid peroxidation and peroxide-scavenging enzymes in cotton seeds under natural ageing. Biol. Plant. 46, 429-434. https://doi.org/ 10.1023/A:1024398724076.

Golovina, E.A., Wolkers, W.F., Hoekstra, F.A., 1997a. Behaviour of membranes and proteins during natural seed ageing. In: Ellis, R.H., Black, M., Murdoch, A.J., Hong, T.D. (Eds.), Basic and Applied Aspects of Seed Biology: Proceedings of the Fifth International Workshop on Seeds, Reading, 1995. Springer, Netherlands, Dordrecht, pp. 787-796. https://doi.org/10.1007/978-94-011-5716-2_86.
Golovina, E.A., Wolkers, W.F., Hoekstra, F.A., 1997b. Long-term stability of protein secondary structure in dry seeds. Comp. Biochem. Physiol. Part A Physiol. 117, 343348. https://doi.org/10.1016/S0300-9629(96)00273-3.

Groot, S.P.C., De Groot, L., Kodde, J., Van Treuren, R., 2015. Prolonging the longevity of ex situ conserved seeds by storage under anoxia. Plant Genet. Resour. Characterisation Util. 13, 18-26. https://doi.org/10.1017/S1479262114000586.

Gutteridge, J.M.C., 1995. Lipid peroxidation and antioxidants as biomarkers of tissue damage. Clin. Chem. 41, 1819-1828 https://doi.org/7497639.

Havas, L., 1935. Ascorbic acid (vitamin C) and the germination and growth of seedlings. Nature 136, 435. https://doi.org/10.1038/136435a0 -435https://doi.org/.

Hawkins, C.L., Morgan, P.E., Davies, M.J., 2009. Quantification of protein modification by oxidants. Free Radic. Biol. Med. 46, 965-988. https://doi.org/10.1016/j.freeradbiomed.2009.01.007.

Hsu, J.L., Sung, J.M., 1997. Antioxidant role of glutathione associated with accelerated aging and hydration of triploid watermelon seeds. Physiol. Plant. 100, 967-974. https://doi.org/10.1034/j.1399-3054.1997.1000424.x.

Job, C., Rajjou, L., Lovigny, Y., Belghazi, M., Job, D., 2005. Patterns of protein oxidation in arabidopsis seeds and during germination. Plant Physiol 138, 790-802. https://doi. org/10.1104/pp.105.062778.

Juszczuk, I.M., Tybura, A., Rychter, A.M., 2008. Protein oxidation in the leaves and roots of cucumber plants (Cucumis sativus L.), mutant MSC16 and wild type. J. Plant Physiol. 165, 355-365. https://doi.org/10.1016/j.jplph.2007.06.021.

Kalemba, E.M., Pukacka, S., 2014. Carbonylated proteins accumulated as vitality decreases during long-term storage of beech (Fagus sylvatica L.) seeds. Trees 28 , 503-515. https://doi.org/10.1007/s00468-013-0967-9.

Kibinza, S., Bazin, J., Bailly, C., Farrant, J.M., Corbineau, F., El-Maarouf-Bouteau, H., 2011 Catalase is a key enzyme in seed recovery from ageing during priming. Plant Sci 181, 309-315. https://doi.org/10.1016/j.plantsci.2011.06.003.

Kibinza, S., Vinel, D., Côme, D., Bailly, C., Corbineau, F., 2006. Sunflower seed deterioration as related to moisture content during ageing, energy metabolism and active oxygen species scavenging. Physiol. Plant. 128, 496-506. https://doi.org/10.1111/ j.1399-3054.2006.00771.x.

Kim, D.H., Han, S.H., Lee, J.C., 2010. Germination and biochemical changes in accelerated aged and osmoprimed seeds. J. Korean For. Soc. 99, 244-250.

Komba, C.G., Brunton, B.J., Hampton, J.G., 2006. Accelerated ageing vigour testing of kale (Brassica oleracea L. var. acephala DC) seed. Seed Sci. Technol 34, 205-208. https://doi.org/10.15258/sst.2006.34.1.23.

Koornneef, M., Bentsink, L., Hilhorst, H., 2002. Seed dormancy and germination. Curr. Opin. Plant Biol. 5, 33-36. https://doi.org/10.1016/S1369-5266(01)00219-9.

Kuchlan, P., Kuchlan, M.K., Husain, S.M., 2017. Effect of foliar application of growth activator, promoter and antioxidant on seed quality of soybean. Legum. Res. 40, $313-$ 318. https://doi.org/10.18805/lr.v0iOF.11302.

Lehner, A., Mamadou, N., Poels, P., Côme, D., Bailly, C., Corbineau, F., 2008. Changes in soluble carbohydrates, lipid peroxidation and antioxidant enzyme activities in the embryo during ageing in wheat grains. J. Cereal Sci. 47, 555-565. https://doi.org/ 10.1016/j.jcs.2007.06.017.

Leubner-Metzger, G., 2003. Functions and regulation of $\beta$-1,3-glucanases during seed germination, dormancy release and after-ripening. Seed Sci. Res. 13, 17-34. https://doi.org/10.1079/ssr2002121.

Leubner-metzger, G., Meins, F.J., 1999. Functions and regulation of plant $\beta$-1, 3glucanases (PR-2). Pathogenesis-Related Proteins in Plants. CRC Press, pp. 49-76.

Li, Y., Qu, J., Dong, Z., Wang, T., An, L., 2008. Storage behavior of Zygophyllum xanthoxylon (Bge.) Maxim seeds at low moisture contents. Acta Physiol. Plant. 30, 651656. https://doi.org/10.1007/s11738-008-0161-7.

Lin, S.S., Pearce, R.S., 1990. Changes in lipids of bean seeds (phaseolus vulgaris) and corn caryopses (zea mays) aged in contrasting environments. Ann. Bot. 65, 451456. https://doi.org/10.1093/oxfordjournals.aob.a087955.

Livesley, M.A., Bray, C.M., 1991. The effects of ageing upon $\alpha$-amylase production and protein synthesis by wheat aleurone layers. Ann. Bot. 68, 69-73. https://doi.org/ 10.1093/oxfordjournals.aob.a088220.

Matthews, S., 1985. Physiology of seed ageing. Outlook Agric. 14, 89-94. https://doi. org/10.1177/003072708501400206.

Mavi, K., Demir, I., 2007. Controlled deterioration and accelerated aging tests predict relative seedling emergence potential of melon seed lots. HortScience 42, 14311435.

Merritt, D.J., Senaratna, T., Touchell, D.H., Dixon, K.W., Sivasithamparam, K., 2003. Seed ageing of four Western Australian species in relation to storage environment and seed antioxidant activity. Seed Sci. Res. 13, 155-165. https://doi.org/10.1079/ ssr2003133.

Mira, S., Estrelles, E., González-Benito, M.E., Corbineau, F., 2011. Biochemical changes induced in seeds of Brassicaceae wild species during ageing. Acta Physiol. Plant 33, 1803-1809. https://doi.org/10.1007/s11738-011-0719-7.

Mira, S., González-Benito, M.E., Hill, L.M., Walters, C., 2010. Characterization of volatile production during storage of lettuce (Lactuca sativa) seed. J. Exp. Bot. 61, 39153924. https://doi.org/10.1093/jxb/erq202.

Mittler, R., 2017. ROS are good. Trends Plant Sci.. https://doi.org/10.1016/j. tplants.2016.08.002.

Moran, J.F., Becana, M., Iturbe-Ormaetxe, I., Frechilla, S., Klucas, R.V., Aparicio-Tejo, P. 1994. Drought induces oxidative stress in pea plants. Planta 194, 346-352. https:// doi.org/10.1007/BF00197534.

Morris, G.J., Goodrich, M., Acton, E., Fonseca, F., 2006. The high viscosity encountered during freezing in glycerol solutions: effects on cryopreservation. Cryobiology 52 323-334. https://doi.org/10.1016/j.cryobiol.2006.01.003.

Murthy, U.M.N., Kumar, P.P., Sun, W.Q., 2003. Mechanisms of seed ageing under different storage conditions for Vigna radiata (L.) Wilczek: lipid peroxidation, sugar 
hydrolysis, Maillard reactions and their relationship to glass state transition. J. Exp. Bot. 54, 1057-1067. https://doi.org/10.1093/jxb/erg092.

North, J., Ndakidemi, P., Laubscher, C., 2012. Effects of antioxidants, plant growth regulators and wounding on phenolic compound excretion during micropropagation of Strelitzia reginae. Int. J. Phys. Sci. 7, 638-646. https://doi.org/10.5897/IJPS11.786.

Ozfidan-Konakci, C. Yildiztugay, E., Kucukoduk, M., 2015. Protective roles of exogenously applied gallic acid in Oryza sativa subjected to salt and osmotic stresses: effects on the total antioxidant capacity. Plant Growth Regul. 75, 219-234. https:// doi.org/10.1007/s10725-014-9946-4.

Parkhey, S., Naithani, S.C., Keshavkant, S., 2012. ROS production and lipid catabolism in desiccating Shorea robusta seeds during aging. Plant Physiol. Biochem. 57, 261267. https://doi.org/10.1016/j.plaphy.2012.06.008.

Pastori, G.M., Kiddle, G., Antoniw, J., Bernard, S., Veljovic-Jovanovic, S., Verrier, P.J., Noctor, G., Foyer, C.H., 2003. Leaf vitamin C contents modulate plant defense transcripts and regulate genes that control development through hormone signaling. Plant Cell 15, 939-951. https://doi.org/10.1105/tpc.010538.

Pearce, R.S., Samad, I.M.A., 1980. Change in fatty acid content of polar lipids during ageing of seeds of peanut (arachis hypogea L.). J. Exp. Bot. 31, 1283-1980. https://doi. org/10.1093/jxb/31.5.1283.

Petruzzelli, L., Taranto, G., 1990. Amylase activity and loss of viability in wheat. Ann. Bot. 66, 375-378. https://doi.org/10.1093/oxfordjournals.aob.a088038.

Powell, a.a., Matthews, S., 2005. Towards the validation of the controlled deterioration vigour test for small seeded vegetables. Seed Test. Int. 129, 21-24.

Priestley, D.A., Leopold, A.C., 1979. Absence of lipid oxidation during accelerated aging of soybean seeds. Plant Physiol. 63, 726-729. https://doi.org/10.1104/pp.63.4.726.

Pukacka, S., 1991. Changes in membrane lipid components and antioxidant levels during natural ageing of seeds of Acer platanoides. Physiol. Plant. 82, 306-310. https://doi.org/10.1111/j.1399-3054.1991.tb00098.x.

Qiusheng, Z., Bao, J., Likun, L., Xianhua, X., 2005. Effects of antioxidants on the plant regeneration and GUS expressive frequency of peanut (Arachis hypogaea) explants by Agrobacterium tumefaciens. Plant Cell. Tissue Organ Cult. 81, 83-90. https:// doi.org/10.1007/s11240-004-3176-9.

Rajjou, L., Lovigny, Y., Groot, S.P.C., Belghazi, M., Job, C., Job, D., 2008. Proteome-wide characterization of seed aging in arabidopsis: a comparison between artificial and natural aging protocols. Plant Physiol 148, 620-641. https://doi.org/10.1104/ pp.108.123141.

Raza, S.H., Shafiq, F., Chaudhary, M., Khan, I., 2013. Seed invigoration with water, ascorbic and salicylic acid stimulates development and biochemical characters of okra (ablemoschus esculentus) under normal and saline conditions. Int. J. Agric. Biol. 15, 486-492.

Saed-Moucheshi, A., Shekoofa, A., Pessarakli, M., 2014. Reactive oxygen species (ROS) generation and detoxifying in plants. J. Plant Nutr. 37, 1573-1585. https://doi.org/ 10.1080/01904167.2013.868483.

Sahu, B., Sahu, A.K., Thomas, V., Naithani, S.C., 2017. Reactive oxygen species, lipid peroxidation, protein oxidation and antioxidative enzymes in dehydrating Karanj (Pongamia pinnata) seeds during storage. South African J. Bot. 112, 383-390. https://doi.org/10.1016/j.sajb.2017.06.030.

Schmidt, A., Kunert, K.J., 1986. Lipid Peroxidation in Higher Plants. Plant Physiol. 82, 700-702. https://doi.org/10.1104/pp.82.3.700.

Sen, B.S., Osborne, D.J., 1977. Decline in ribonucleic acid and protein synthesis with loss of viability during the early hours of imbibition of rye (secale cereale L.) embryos. Biochem. J. 166, 33-38.

Sershen, Berjak, P., Pammenter, N.W., Wesley-Smith, J., 2012. The effects of various parameters during processing for cryopreservation on the ultrastructure and viability of recalcitrant zygotic embryos of Amaryllis belladonna. Protoplasma 249, 155-169. https://doi.org/10.1007/s00709-011-0274-5.

Sershen, Varghese, B., Naidoo, C., Pammenter, N.W., 2016. The use of plant stress biomarkers in assessing the effects of desiccation in zygotic embryos from recalcitrant seeds: challenges and considerations. Plant Biol. 18, 433-444. https://doi.org/ $10.1111 / \mathrm{plb} .12428$.

Shaban, M., 2013. Review on physiological aspects of seed deterioration. Int. J. Agric. Crop Sci. 6, 627-631.

Shao, H.bo, Chu, L.ye, Shao, M.an, Jaleel, C.A., Hong-mei, M., 2008. Higher plant antioxidants and redox signaling under environmental stresses. Comptes Rendus - Biol. 331, 433-441. https://doi.org/10.1016/j.crvi.2008.03.011.

Simon, E.W., 1974. Phospholipids and plant membrane permeability. New Phytol 73 $377-420$.

Smith, M.T., 1986. Membrane Changes and Lipid Peroxidation During Ageing in Seeds of Lactuca Sativa L. University of Natal, Durban.

Tabatabaei, S.A., 2013. The effect of priming on germination and enzyme activity of sesame (sesamum indicum L.) seeds after accelerated aging. J. Stress Physiol. Biochem. 9, 132-138.

Tekrony, D.M., 2005. Accelerated aging test: principles and procedures. Seed Technol. 27, 135-146.

Tiryaki, I., Buyukcingil, Y., 2009. Seed priming combined with plant hormones: influence on germination and seedling emergence of sorghum at low temperature. Seed Sci. Technol. 37, 303-315. https://doi.org/10.15258/ sst.2009.37.2.05.

Tisserat, B., Stuff, A., 2011. Stimulation of short-term plant growth by glycerol applied as foliar sprays and drenches under greenhouse conditions. HortScience 46, 1650 1654.

van Staden, J., Davey, J.E., du Plessis, L.M., 1976. Lipid utilization in viable and non-viable protea compacta embryos during germination. Zeitschrift für Pflanzenphysiologie 77, 113-119. https://doi.org/10.1016/s0044-328x(76)80173-0.

Varghese, Boby, Sershen, Berjak, Patricia, Varghese, Dalia, Pammenter, W., Norman, 2011. Differential drying rates of recalcitrant Trichilia dregeana embryonic axes: A study of survival and oxidative stress metabolism. Physiologia Plantarum 142 (4), 326-338. https://doi.org/10.1111/j.1399-3054.2011.01469.x.

Varier, A., Vari, A.K., Dadlani, M., 2010. The subcellular basis of seed priming. Curr. Sci. 99, 450-456

Verma, G., Mishra, S., Sangwan, N., Sharma, S., 2015. Reactive oxygen species mediate axis-cotyledon signaling to induce reserve mobilization during germination and seedling establishment in Vigna radiata. J. Plant Physiol. 184, 79-88. https://doi. org/10.1016/j.jplph.2015.07.001.

Wang, W., He, A., Peng, S., Huang, J., Cui, K., Nie, L., 2018. The effect of storage condition and duration on the deterioration of primed rice seeds. Front. Plant Sci. 9, 1-17. https://doi.org/10.3389/fpls.2018.00172.

Xue, T., Hartikainen, H., Piironen, V., 2001. Antioxidative and growth-promoting effect of selenium on senescing lettuce. Plant Soil 237, 55-61. https://doi.org/10.1023/ A: 1013369804867.

Yan, H.-.F., Mao, P.-.S., Sun, Y., Li, M.-.L., 2015. Impacts of ascorbic cid on germination, antioxidant enzymes and ultrastructure of embryo cells of aged Elymus sibiricus seeds with different moisture contents. Int. J. Agric. Biol. 18, 176-183. https://doi. org/10.17957/IJAB/15.0092.

Yan, Hui-Fang, Mao, Pei-Sheng, Sun, Yan, Li, Man-Li, 2016. Impacts of ascorbic acid on germination, antioxidant enzymes and ultrastructure of embryo cells of aged Elymus sibiricus seeds with different moisture contents. International Journal of Agriculture and Biology 18 (1), 176-183. https://doi.org/10.17957/ IJAB/15.0092.

Yatim, R.M., Kannan, T.P., Ab Hamid, S.S., 2016. Effect of gamma radiation on the expression of mRNA growth factors in glycerol cryopreserved human amniotic membrane. Cell Tissue Bank 17, 643-651. https://doi.org/10.1007/s10561-0169576-3.

Yin, G., Xin, X., Fu, S., An, M., Wu, S., Chen, X., Zhang, J., He, J., Whelan, J., Lu, X., 2017. Proteomic and carbonylation profile analysis at the critical node of seed ageing in Oryza sativa. Sci. Rep. 7, 40611. https://doi.org/10.1038/srep40611. 